\title{
Long-term field experiments in Germany: classification and spatial representation
}

\author{
Meike Grosse $^{1}$, Wilfried Hierold ${ }^{1}$, Marlen C. Ahlborn ${ }^{1}$, Hans-Peter Piepho ${ }^{2}$, and Katharina Helming ${ }^{1}$ \\ ${ }^{1}$ Leibniz Centre for Agricultural Landscape Research (ZALF), \\ Eberswalder Straße 84, 15374 Müncheberg, Germany \\ ${ }^{2}$ Biostatistics Unit, Institute of Crop Science, University of Hohenheim, 70599 Stuttgart, Germany
}

Correspondence: Meike Grosse (meike.grosse@zalf.de)

Received: 14 May 2020 - Discussion started: 16 June 2020

Revised: 24 September 2020 - Accepted: 15 October 2020 - Published: 26 November 2020

\begin{abstract}
The collective analysis of long-term field experiments (LTFEs), here defined as agricultural experiments with a minimum duration of 20 years and research in the context of sustainable soil use and yield, can be used for detecting changes in soil properties and yield such as those induced by climate change. However, information about existing LTFEs is scattered, and the research data are not easily accessible. In this study, meta-information on LTFEs in Germany is compiled and their spatial representation is analyzed. The study is conducted within the framework of the BonaRes project, which, inter alia, has established a central access point for LTFE information and research data. A total of 205 LTFEs which fit to the definition above are identified. Of these, 140 LTFEs are ongoing. The land use in 168 LTFEs is arable field crops, in 34 trials grassland, in 2 trials vegetables and in 1 trial pomiculture. Field crop LTFEs are categorized into fertilization $(n=158)$, tillage $(n=38)$ and crop rotation $(n=32$; multiple nominations possible) experiments, while all grassland experiments $(n=34)$ deal with fertilization. The spatial representation is analyzed according to the climatic water balance of the growing season (1 May to 31 October) (CWBg), the Müncheberg Soil Quality Rating (MSQR) and clay content. The results show that, in general, the LTFEs well represent the area shares of both the CWBg and the MSQR classes. Eighty-nine percent of the arable land and $65 \%$ of the grassland in Germany are covered by the three driest CWBg classes, hosting $89 \%$ and $71 \%$ of the arable and grassland LTFEs, respectively. LTFEs cover all six MSQR classes but with a bias towards the high and very high soil quality classes. LTFEs on arable land are present in all clay content classes according to the European Soil Data Centre (ESDAC) but with a bias towards the clay content class 4. Grassland LTFEs show a bias towards the clay content classes 5, 6 and 7, while well representing the other clay content classes, except clay content class 3 , where grassland LTFEs are completely missing. The results confirm the very high potential of LTFE data for spatially differentiated analyses and modeling. However, reuse is restricted by the difficult access to LTFE research data. The common database is an important step in overcoming this restriction.
\end{abstract}

\section{Introduction}

Long-term field experiments (LTFEs) are a valuable research infrastructure for terrestrial research in general and in agricultural research in particular. They are here defined as agricultural field experiments with a minimum duration of 20 years and research in the context of sustainable soil use and yield. Changes in soil properties tend to occur slowly; thus, for the identification of long-term trends, experiments with a long duration are needed. However, a single LTFE allows for the drawing of conclusions only for its specific site. The collective analysis of research data from different LTFEs at different locations leads to more generalizable results. On the one hand, similar experiments on similar sites will lead to better validated conclusions when analyzed in combination. On the other hand, LTFEs in different experimental conditions may lead to broader implementable results by 
their collective analysis. Furthermore, LTFEs are expensive; a comprehensive and coordinated evaluation is also required to prove that they are worth the expense (Körschens, 2006; Berti et al., 2016). Historically, LTFEs were mainly established to answer questions regarding plant nutrition in the sense of achieving the highest possible yield (Merbach and Deubel, 2008). Later, they were used to reveal the effects of agricultural management practices (besides fertilization mainly tillage and crop rotation) on crop yield but also soil characteristics. LTFEs have been very helpful for research on soil organic carbon content or composition (Ellerbrock and Gerke, 2016; Kaiser et al., 2014; Körschens et al., 2014). LTFEs are further important for research related to questions regarding the interannual variability of crop yield (i.e., yield stability) that can be associated with climate change (Berti et al., 2016; Reckling et al., 2018; Macholdt et al., 2019a) and respective adaptation options (Hamidov et al., 2018). Valuable data can also be delivered for the validation of models (Franko et al., 2011; Ellerbrock et al., 2005) and for concepts used to evaluate soil functions (Vogel et al., 2019; Techen et al., 2020).

The joint analysis of LTFEs can go beyond the original research question of each LTFE, e.g., to answer questions about climate change, ecosystem services, nutrient cycles or yield stability. This research could be done through the common assessment of the "control" treatment of each LTFE, which is here defined as a treatment with customary tillage and fertilization and is present in most LTFEs. The combined analysis of control treatments is irrespective of the LTFE's original research theme. This would allow us to reveal changes in soil properties independently of the original questions for which the experiments were set up, e.g., overall trends in carbon content development. Although that would be a similar analysis to what can be done with soil monitoring sites ("Bodendauerbeobachtungsflächen", i.e., a permanent monitoring program where the federal states of Germany have the responsibility for recording changes in soils of cropland, grassland, forests and specialized crops), it would be a reasonable approach. It can be assumed that LTFEs have fewer breaks during the experimental period than soil monitoring sites, as soil monitoring sites are always a "window" into real agriculture. Further on, access to data from soil monitoring sites is not necessarily easier than that to LTFEs. Of course, the strengths of the collective analysis of LTFEs is the analysis of LTFEs with similar treatments in the form of a meta-analysis.

The meta-analyses of similar LTFEs, e.g., of fertilizer experiments with similar factors (e.g., with or without organic manure) or tillage experiments (e.g., conventional tillage vs. reduced tillage), have the opportunity to make use of the original research question of the LTFE. The effects and sustainability of measures can be revealed in a broader context and in different soils. This can be done with pairwise comparisons of alternative and reference management practices, such as that by Bai et al. (2018) and Sandén et al. (2018).
However, because of the site specificity of soil-plant interactions and their responses to agricultural management practices, the upscaling and generalization of results require information about the spatial representation of LTFE sites.

The statistical analysis of LTFEs poses several challenges and requires careful statistical modeling. We would recommend a mixed-model-based analysis that accounts for the randomized layout of the trial (see Onofri et al., 2016, for a review and some case studies). A general strategy starts out from the analysis model that would be used for a single year of data and then extends the model to account for variation across years. A specific challenge here is that during the course of the experiment several observations are made on the same experimental units, and this serial correlation needs to be taken into account (Payne et al., 2015; Richter and Kroschewski, 2006; Singh and Jones, 2002). Also, there may be heterogeneity of variance between years, which may be related to changes in stability of the investigated systems (Macholdt et al., 2019a, b).

A common issue with several LTFEs in Germany is that they were not properly randomized. This is mainly due to the fact that Fisher's principles of randomization and blocking were not widely known or accepted at the time when these trials were established. Instead, the systematic design originally proposed by Mitscherlich about a hundred years ago was very popular, and several LTFEs were established according to such systematic designs. For these unrandomized trials, a randomization-based analysis is obviously not available. One option then is to try spatial modeling, though it must be stressed that fitting of a spatial covariance structure cannot make up for a lack of randomization. But such a modeling is perhaps the best way forward if a sensible analysis is to be conducted for such trials. For a review of the connection between systematic designs as proposed by Mitscherlich and certain spatial covariance structures, see Piepho and VoThanh (2020).

Important compilations of German LTFEs have been performed by Körschens $(1994,1997)$ and Debreczeni and Körschens (2003). In Körschens (1994), 97 German LTFEs with a duration of more than 20 years were listed. The starting year, the kinds of factors, the cultivated crops, the size of the plots and experiments, the soil texture, the average annual air temperature, and the average annual precipitation of the site are presented if available. In Körschens (1997), 50 German LTFEs with a duration of more than 30 years are listed, and similar information is presented. In Debreczeni and Körschens (2003), 94 German LTFEs with a duration of more than 20 years are listed, and information about the start, experimental aspects, cropping system and soil is provided. Körschens $(1994,1997)$ indicate the following constraints for the compilation of a complete overview of all LTFEs in Germany: the multitude of experiments, discontinued experiments, new experiments or experiments not at all documented in the literature. In Debreczeni and Körschens (2003), restricted resources for data collection are also men- 


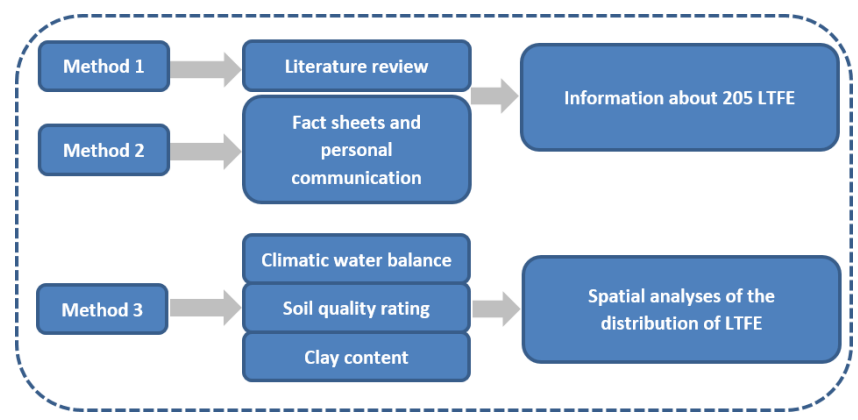

Figure 1. Methods used for assessing the representativeness of the LTFE distribution in Germany.

tioned. In addition, the heterogeneous setup and the scattered distribution of LTFEs make comparisons of data difficult or impossible (Bai, 2018). To cope with these problems, in the frame of the project "BonaRes", funded by the German Federal Ministry for Education and Research (BMBF), there is a focus on a central database for metadata and research data from LTFEs (BonaRes, 2020). The research data from two LTFEs (V140, Müncheberg and Dikopshof, Bonn) are available for free reuse via the BonaRes data portal (https://maps.bonares.de/mapapps/, last access: 20 November 2020) and the research data of nine other LTFEs are very close to publication. More LTFE holders will hopefully agree to upload research data within the third (and last) funding phase of BonaRes and take the great chance for support in data processing and storage.

No information is yet available regarding the spatial representation of LTFEs in Germany with regard to important agronomic factors such as climate and soil fertility. The aim of this paper was twofold. First, to classify the LTFEs in Germany with regard to land use, research themes and farming systems. Second, the aim was to conduct a descriptive analysis of the geospatial distribution of the experimental sites with regard to key factors of agricultural production: climate and soil fertility.

\section{Material and methods}

A combination of three methods was applied: a literature review to identify LTFEs in Germany, a fact-sheet-based addition of information to the identified LTFEs and a geospatial analysis employing the CWBg and the MSQR (Fig. 1).

An extensive literature review was conducted to identify LTFEs. The search terms were "long-term field experiment", "long-term experiment", "long-term field trial" and "longterm trial", as well as the German terms "Dauerfeldversuch", "Dauerdüngungsversuch", "Dauerversuch", "Langzeitfeldversuch" and "Langzeitversuch". Sources were scientific papers as well as other articles, books, trial guides and websites. The focus was on the exact position of the LTFE and the following metadata: name of the LTFE, website (if avail- able), institution, land use category, participation in existing networks, research theme, size of the LTFE area, number of plots, size of the plots, crop rotation, start (and maybe end) of the trial, measured parameters and trial setup including factors, treatments and randomization. For the coordination and simplification of the trial description, the BonaRes fact sheet was established, which asks for all relevant trial information (Grosse et al., 2019). It was sent to the trial holders, and the fact sheet was completed for 40 trials. Trial holders also delivered important information as personal communication. In compiling the dataset, special attention was paid to LTFEs with a minimum duration of 20 years. This age can be seen as a threshold for the identification of longterm trends. Attention was given to LTFEs in the context of soil research, i.e., the objects of research should at least include soil properties and yield as an important soil function. The setup of each trial should allow for statistical analyses, i.e., have clearly defined treatment factors, replications and as much as possible a static design. Lysimeter experiments were excluded because they were considered their own category. Some reasons for this exclusion are that soils are often transferred and not undisturbed in lysimeter experiments, and tillage has to be conducted by hand instead of machines, which can bias some results. Indeed, long-term lysimeter experiments exist in Germany as part of the TERENO network (TERENO, 2020).

The LTFEs were classified according to their research themes to simplify the identification of similar experiments. The field crop LTFEs could best be grouped into four clusters: fertilization, tillage, crop rotation and other. The fourth cluster "other" entails all themes that could not be grouped into the first three and appeared only in a few (maximum five) LTFE cases, so a separate group was not justified. Two or more factorial experiments were sorted in all relevant classes; i.e., multiple nominations were possible. LTFEs on grassland exist only as fertilization trials.

There are 109 LTFEs precisely known in their position, and for an additional 96 LTFEs, the trial area is approximately known, usually on the area of the holding institution. In the latter case, either the exact position is not known or the former LTFEs are now overbuilt with streets, parking spaces or buildings.

The geospatial analysis was performed by comparing the regional distribution of LTFEs to that of (a) climatic water balance classes of the growing season (1 May to 31 October) (CWBg) and (b) the Müncheberg Soil Quality Rating (MSQR) as two complex site classifications. In addition, (c) clay content of the topsoil according to ESDAC (2020) was chosen. The representativeness of LTFEs according to the frequencies in the cells of this classification was assessed. LTFEs were classified according to their land use and their research themes to simplify the identification of similar experiments. The identification of suitable LTFEs in similar (or different) landscapes shall be facilitated. Therefore, a table with the IDs of all experiments, their thematic classification, 
their CWBg class and their MSQR class is provided in the Appendix. More details for each LTFE can be identified in the published dataset (Grosse and Hierold, 2019), which is freely available in the BonaRes Repository, by the ID of the LTFE. Thus, cooperation with LTFE holders can be initiated more easily. Fourteen LTFEs were excluded from the geospatial analysis because they were dealing with research themes other than fertilization, tillage or crop rotation, or they did not include field crops or grassland experiments. The remaining 191 LTFEs were grouped into the following four classes: fertilization experiments, tillage experiments, grassland experiments and crop rotation experiments. The shares of LTFEs in each class were compared to those of agricultural land in Germany. For that, approximately $17.9 \times 10^{6}$ ha of agricultural land was subdivided according to its land use as arable land (approximately $13.5 \times 10^{6} \mathrm{ha}$ ) or grassland (approximately $4.4 \times 10^{6}$ ha) (Umweltbundesamt, 2019). For the descriptive statistical analyses, cross-tabulations and contingency tables were used.

The CWBg was chosen as a suitable parameter to represent the climatic conditions for agricultural land use and because of its huge relevance for vegetation growth. Its impact may be even larger than that of temperature (Crimmins et al., 2011), and it may determine the growing season (Sattar et al., 2019). We used data from the German Meteorological Service (DWD) for the period 1981-2010 for the main growing season, defined from 1 May to 31 October (Ad-hoc-AG Boden, 2005). The climatic water balance (CWB) data for the growing season instead of the whole year were chosen, because regional differentiation is bigger for CWBg compared to the annual balance. The data are available for the whole territory of Germany with a pixel resolution of $1 \mathrm{~km}$ (DWD, 2020). The CWB is defined in Eq. (1) as the difference in precipitation $(P)$ and potential evapotranspiration (PET). It is a quantitative measure of the water supply in a given time period and for a specific region. The PET depends on location factors such as crop cover, topographical effects, soil conditions and soil water storage. It can therefore only be determined selectively. However, for a better comparison for spatial calculations, the so-called grass reference evapotranspiration is considered, which indicates the evapotranspiration of a standardized grass cover in standardized soil with optimal water supply (Pereira et al., 2015).

$$
\mathrm{CWB}=P-\mathrm{PET}
$$

The classification of the climatic water balance into seven classes follows the German Soil Survey Guidelines KA5 (Ad-hoc-AG Boden, 2005) ( $\leq 150 \mathrm{~mm} ;-150$ to $<-50 \mathrm{~mm}$; -50 to $<50 \mathrm{~mm} ; 50$ to $<150 \mathrm{~mm} ; 150$ to $<300 \mathrm{~mm} ; 300$ to $<500 \mathrm{~mm}$; $\geq 500 \mathrm{~mm}$ ), which are classified there from extremely low to extremely high (Ad-hoc-AG Boden, 2005).

To derive data for agricultural areas, either arable land or grassland intersections with the CORINE Land Cover (CLC, 2018) dataset were made.
For point (b), a soil quality map (BGR, 2014) is used, which applies the Müncheberg Soil Quality Rating (MSQR). It has a pixel resolution of $250 \mathrm{~m}$. The Institute for Geosciences and Natural Resources (BGR) had applied this complex assessment procedure (Mueller et al., 2010; Ad-hoc-AG Boden, 2010), which was developed as a visual procedure for estimating yield potential in the field, by modeling data from the soil overview map (BGR, 2007), but only for arable land. It takes soil structure and soil degradation threats into account and integrates 8 basic soil indicators with 13 hazard indicators into a rating of soil quality. The rating is shown on an ordinal scale of 0 to 102 and clustered into six quality classes, with higher values indicating higher yield potential (Daedlow, 2018). The 8 soil indicators are substrate, A-horizon depth, topsoil structure, subsoil structure, rooting depth, profile available water, wetness and ponding, and slope and relief. The 13 hazard indicators are contamination, salinization, sodification, acidification, low total nutrient status, shallow soil depth above hard rock, drought, flooding and extreme waterlogging, steep slope, rock and surface, high percentage of coarse texture fragments, a soil thermal regime unsuitable for crop production, and miscellaneous hazards (e.g., exposure to wind and water erosion). Most of the indicators are sensitive to agricultural management, which makes the MSQR most useful for studying the effects of agricultural management on soil. The MSQR has been proven useful in other studies of geospatial representation (Askari et al., 2013; Hanauer et al., 2017; Smolentseva et al., 2014). Since no MSQR is available for grassland areas, the LTFEs on grassland were excluded in this analysis.

Out of the 157 fertilization, tillage or crop rotation LTFEs on arable land, 26 could not be assigned to a class of MSQR, because the fields were surrounded by buildings and were therefore not part of arable land. If an LTFE did not obtain an assignment at a GIS (geographic information system) intersection, the value was determined manually by plausible examination of the nearest five to seven grid cells. One LTFE could not be assigned to a class of MSQR because it compares three different soils in boxes.

For point (c), clay content, data of the European Soil Data Centre (ESDAC) based on LUCAS topsoil data are used (ESDAC, 2020). Although clay content is included in the MSQR as part of substrate, we decided to analyze the area shares of clay content separately, as carbon content is often correlated with the clay content (Körschens, 1997). Moreover, clay content is needed to estimate the carbon balance in a model derived from the CANDY model (Franko et al., 2011). Furthermore, ESDAC offers international data; therefore, clay content is suitable for international comparability. Due to the fact that texture is part of the MSQR, we do not offer separate maps for clay content but present data in tables.

Calculations always refer to utilized agricultural areas or parts thereof, arable land or grassland. 


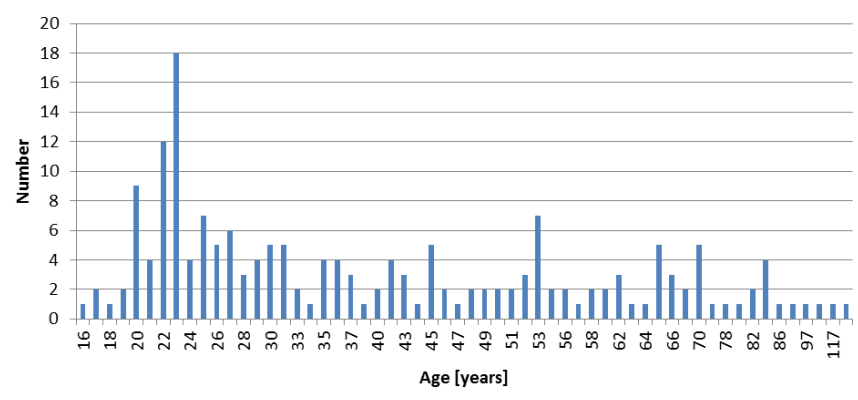

Figure 2. Number of LTFEs per age in 2019 ( $n=183$; age of 22 LTFEs unknown).

The information was analyzed with Microsoft Excel. The geospatial analysis was performed using the ESRI software ArcMap 10.6.1 (ESRI, 2018).

The research on LTFEs is not completed but is ongoing. The information about LTFEs is continuously updated and expanded. New LTFEs are integrated, and the information about each LTFE is extended. The state of research is November 2019.

\section{Results and discussion}

\subsection{Overview of LTFEs in Germany}

In total, 205 LTFEs across Germany with a minimum duration of 20 years were identified, of which 140 trials are ongoing and 65 are terminated (status: November 2019). Further LTFEs reaching the 20-year threshold within the next 5 years (until 2024) were also included ( $n=6$; Fig. 2). Most of the trials have a duration between 20 and 49 years $(n=124$; Fig. 2). Fifty trials have a duration between 50 and 99 years. Three trials have been running for more than 100 years ("Ewiger Roggen", Halle, 1878-today; "Statischer Düngungsversuch V120", Bad Lauchstädt, 1902-today; "Dauerdüngungsversuch Dikopshof", Wesseling, 1904-2009). The age of 22 terminated trials is unknown since only the starting date of the trials is known but not the exact ending year. As these trials were mentioned in different important sources as being ongoing (Amberger and Gutser, 1976; Debreczeni and Körschens, 2003; Körschens, 1990, 1994, 1997, 2000), it is known that their duration was at least 20 years.

The land use in 168 LTFEs is arable field crops, in 34 trials grassland, in 2 trials vegetables and in 1 trial pomiculture. There are more long-term grassland experiments in Germany; we have not included them in our research because they are dedicated to research themes other than questions of sustainable soil use and yield.

The majority of LTFEs were established after 1947, when research was resumed after the Second World War (Fig. 3). In 1996/1997, a series of grassland fertilization experiments was established by several German state authorities. This ex- plains the high number of LTFEs established in these years (Fig. 3).

The research themes of the LTFEs can be assigned to the following categories: fertilization, tillage, crop rotation, other themes and combinations of these (Table 1). Due to trials with two or more treatment factors, multiple nominations of experiments for the different research themes were assigned $(n=251)$. Most LTFEs were established for research on fertilization (Fig. 3 and Table 1) $(n=158)$. This result is coincident with the results from a study in the international context (Berti et al., 2016). In Germany, fertilization LTFEs can be subdivided into field crop experiments $(n=124)$ and grassland experiments $(n=34)$. Historically, questions regarding the effects of fertilization on plant growth were the focus of research, while more recently the effects on the soil and the environment are investigated. The focus of the experiments is different kinds of fertilizers, different amounts of fertilizers, comparisons with or without a specific fertilizer, or combinations of these. Most frequently, organic fertilization versus mineral $\mathrm{N}$ fertilization is examined. In fewer experiments, the effect of straw fertilization is the subject of research. Additionally, the effects of mineral $\mathrm{K}$ fertilization, mineral $\mathrm{P}$ fertilization, liming, green manure, mineral $\mathrm{Mg}$ fertilization, compost or sludge are examined (Table 1). More rarely, different points in time of the fertilizing measure are compared.

Thirty-eight LTFEs address tillage variations (Table 1). Most of these tillage experiments compare different tillage intensities. Most often, reduced tillage depth or conservation tillage are the subjects of research. Also, inversion versus non-inversion tillage is compared. Further research themes are sowing methods, different forms of primary tillage, the effects of stubble tillage and tillage frequency (Table 1). The oldest tillage experiment started in 1923 (Statischer Dauerversuch Bodennutzung, Berlin-Dahlem), but 25 tillage experiments started in 1990 or later (Fig. 3). Therefore, most of the tillage experiments are "younger" experiments, a result also congruent with the findings by Berti et al. (2016).

Thirty-two LTFEs have the research theme "crop rotation". Mostly, the effect of crop rotation on soil properties and yield is investigated. Therefore, rotational cropping versus monoculture is compared. Additionally, plant health is the focus, e.g., compatibility of different cereal species or different percentages of cereals in crop rotation (Table 1). Most of the crop rotation experiments were established after 1950. Nineteen experiments of the 32 crop rotation experiments are still ongoing. The oldest crop rotation experiment, the "Eternal Rye", was established in 1878 by the Martin Luther University of Halle.

Twenty-three trials address research themes other than fertilization, tillage or crop rotation. The other research themes are highly diverse. "Environmentally friendly crop protection", mainly reduced pesticide intensity, is the most frequent research theme among the other research themes $(n=5)$. "Irrigation" is the second most frequent $(n=4)$. "Effects of different forms of fallow" is within the focus of three LTFEs. 


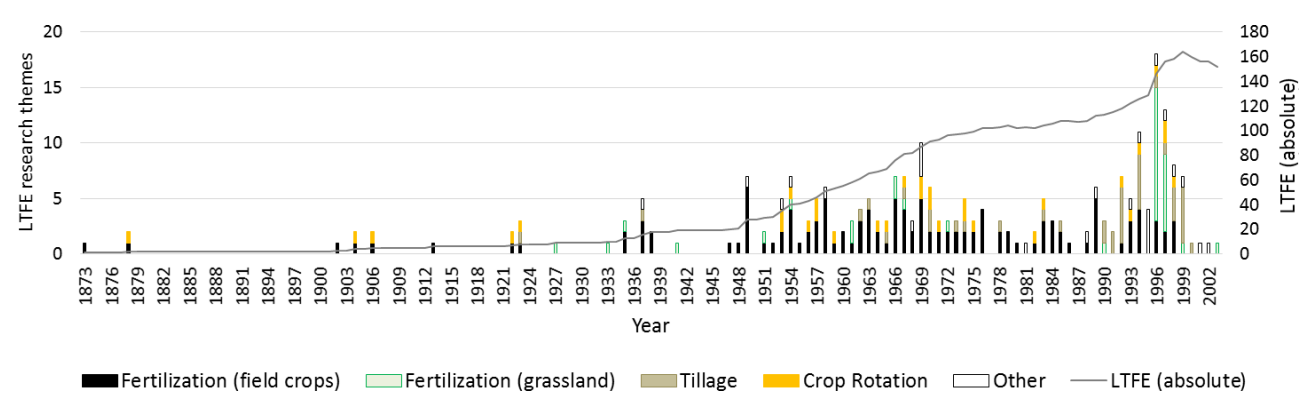

Figure 3. Number of LTFEs set up per year according to the research themes of the experiments (multiple nominations possible, $n=251$ ) and total number of LTFEs per year (meaning established LTFE minus terminated LTFE).

"Frequency and start of utilization of grassland", "Land use systems comparison", "Monitoring of organic farming" and "Use of biodynamic preparations" are each within the focus of two LTFEs. Three other research themes are present in only one LTFE (Table 1).

Many different parameters are measured in LTFEs. In Grosse et al. (2019), 46 different soil parameters and 29 plant parameters are listed, which were measured in LTFEs. The analyzed parameters can be assigned to different soil functions. The following five soil functions were chosen as most relevant for BonaRes: biomass production, water storage and filtering, nutrient storage and recycling, carbon storage, and habitat for biological activity. In most LTFEs, parameters for biomass production were measured like yield and yield components. Nutrient storage and recycling is the second most frequent soil function. Less research is conducted (in decreasing frequency) for carbon storage, habitat for biologic activity, and water storage and filtering.

Archived samples are an important means of performing or repeating measurements. However, the information (if archived samples exist) is difficult to find in the literature. We have the information from a fact sheet query.

Of 40 responses received, 32 LTFEs have archived samples. A total of 184 trials are set up with conventional management practices, 14 with organic management practices and five with so-called integrated agriculture. Two trials compare conventional with organic management practices.

The holding institution for 96 trials is a university or university of applied sciences, and for 61 trials, it is a state authority. Twenty-seven trials are in the responsibility of nonuniversity scientific institutions such as research institutes. 21 trials are or were held by industry.

Compared to LTFEs worldwide, there are a comparatively large number of LTFEs in Germany. Our research revealed (up to now) 177 LTFEs which match our definition in the following countries: Austria, Belarus, Belgium, Bulgaria, China, Czech Republic, Denmark, Estonia, Finland, France, Hungary, Ireland, Italy, Moldova, Norway, Poland, Romania, Russia, Slovenia, Spain, Sweden, Switzerland, UK, Ukraine and USA. They are comparable in age (the oldest ones started in 1843) and research themes. There are in- ternational networks such as the working group IOSDV (Internationale Organische Stickstoffdauerdüngungsversuche; Körschens, 2000), the GLTEN (Global Long-Term Experiment Network, which was launched in 2018; GLTEN, 2020) and networks of organic LTFEs like RetiBio in Italy and the RotAB network in France (Ciaccia et al., 2020). In order to make the best use of the great efforts and costs that are behind every single LTFE, international networks should cooperate more intensively in future and possibly also use data infrastructure jointly. We would like to point out that the BonaRes data repository can also be used by international data holders.

All information about the LTFEs in Germany is published in an online overview map (https://ttfe-map.bonares.de, last access: 20 November 2020). The aims of the overview map are to make LTFEs more visible, to enhance networking among LTFEs and to simplify joint analyses of LTFEs. It is available in German and English. The map content can be displayed according to different categories, e.g., the research themes, land use or duration of the LTFEs. In addition to the overview information, details about every single LTFE are provided in a pop-up window, offering valuable information for potential users for orientation and initiation of cooperation.

As limitations of existing LTFEs, it can be mentioned that erosion and compaction are typically not analyzed in LTFEs, and they are not designed for such questions up to now. Grassland experiments are in fact meadow experiments, whereas grazing experiments are completely missing.

\subsection{Geospatial analyses}

\subsubsection{Geospatial analysis of LTFEs in relation to the climatic water balance of the growing season (CWBg) distribution}

An overview of the distribution of these CWBg classes and of LTFEs in Germany is given in Fig. 4. According to Table 2 and Fig. 4, arable land is distributed among classes 1-7 of the CWBg (Table 2; Fig. 4): the largest shares of $33 \%$ each are classified as CWBg classes 2 (from -150 to $<-50 \mathrm{~mm}$ ) or 3 (from -50 to $<50 \mathrm{~mm}$ ), respectively. The area of CWBg class 2 is mainly located in the lowlands of 
Table 1. Research themes in LTFEs (multiple nominations possible, sorted by frequency).

\begin{tabular}{|c|c|}
\hline Theme & $\begin{array}{l}\text { Number } \\
\text { of trials }\end{array}$ \\
\hline Fertilization - field crop experiments & 124 \\
\hline Manure fertilization & 58 \\
\hline Mineral $\mathrm{N}$ fertilization & 55 \\
\hline Straw fertilization & 24 \\
\hline Mineral $\mathrm{K}$ fertilization & 15 \\
\hline Mineral P fertilization & 14 \\
\hline Liming & 10 \\
\hline Green manure (with vs. without) & 8 \\
\hline Mineral fertilization (not specified) & 6 \\
\hline Mineral Mg fertilization & 4 \\
\hline Compost & 3 \\
\hline Sludge & 2 \\
\hline Tillage - field crop experiments & 38 \\
\hline Reduced depth or conservation tillage & 24 \\
\hline Inversion vs. non-inversion tillage & 12 \\
\hline Sowing methods & 10 \\
\hline Different forms of primary tillage & 7 \\
\hline Stubble tillage (with vs. without) & 3 \\
\hline Tillage frequency & 3 \\
\hline Other & 2 \\
\hline Fertilization - grassland experiments & 34 \\
\hline Mineral $\mathrm{P}$ fertilization & 11 \\
\hline Mineral $\mathrm{K}$ fertilization & 10 \\
\hline Mineral $\mathrm{N}$ fertilization & 6 \\
\hline Liming & 4 \\
\hline Manure fertilization & 2 \\
\hline Sludge & 2 \\
\hline Mineral fertilization (not specified) & 1 \\
\hline Acid vs. alkaline fertilization & 1 \\
\hline Crop rotation - field crop experiments & 32 \\
\hline Crop rotation (not specified) & 23 \\
\hline Rotational cropping vs. monoculture & 4 \\
\hline Effect of pre-crop & 2 \\
\hline Crop rotation organic vs. integrated & 1 \\
\hline Different percentages of cereals & 1 \\
\hline Different percentages of wheat & 1 \\
\hline Other - field crop and grassland experiments & 23 \\
\hline Crop protection & 5 \\
\hline Irrigation & 4 \\
\hline Effects of different forms of fallow & 3 \\
\hline Frequency and start of utilization of grassland & 2 \\
\hline Land use systems comparison & 2 \\
\hline Monitoring of organic farming & 2 \\
\hline Use of biodynamic preparations & 2 \\
\hline Chopped woody plants for weed suppression & 1 \\
\hline Effect of weather conditions & 1 \\
\hline Thistle control & 1 \\
\hline
\end{tabular}

Germany: in the western and northern Rhine-Main valley, in a majority of the northeastern lowland and an area around Magdeburg called the Loess Boerde. The area of CWBg class 3 is mainly distributed in the northeastern part of Germany as well as in parts of the South German Escarpments landscape, the northern foothills of the Alps (lower Bavarian upland) and the lower uplands, such as the Lower Saxon and Hessian lowlands, the Vogtland district (a region in the border area of Bavaria, Saxony, Thuringia and Bohemia) and the Ore Mountain foreland. Twenty-three percent of the arable land is allotted to CWBg class $1(<-150 \mathrm{~mm})$. This extremely low CWBg is located almost exclusively in eastern Germany, especially in the rain shadow of the Harz: the Fläming (a landscape in southwest Brandenburg and eastern SaxonyAnhalt), the plates and lowlands of mid Brandenburg and the heathland of Brandenburg. Minor shares of $7 \%$ and $4 \%$ are allotted to CWBg classes 4 (from 50 to $<150 \mathrm{~mm}$ ) and 5 (from 150 to $<300 \mathrm{~mm}$ ), respectively. CWBg class 4 is located mainly in the foothills of the Alps as well as around the secondary mountains and in the western Schleswig-Holstein (moraines of Schleswig-Holstein). CWBg class 5 is mainly located in Germany's southern foothills of the Alps. CWBg class 6 (from 300 to $<500 \mathrm{~mm}$ ) is not present in Germany's arable land and CWBg class 7 (>500 $\mathrm{mm}$ ) is not present in Germany's agricultural land (arable and grassland).

Among the grassland, the largest share of $33 \%$ is classified as CWBg class 3 (Table 3). Twenty-three percent of grassland is classified as $\mathrm{CWBg}$ class 5. Eighteen percent is classified as $\mathrm{CWBg}$ class $2,14 \%$ as CWBg class 1 and $9 \%$ as CWBg class 4 . CWBg class 6 is present in a small share $(3 \%)$ of Germany's grassland at higher altitudes in the Alpine region.

To analyze sites in every CWBg class, each class would have to be represented through LTFEs. Ideally, the shares of LTFEs in each class would correspond to the agricultural area. This is, of course, not the case (Table 2), as LTFEs were not established systematically in the landscape. Each CWBg class present in the arable land is represented by LTFEs, but they are not found in the same shares. CWBg class 1 is overrepresented by all LTFE types, CWBg class 2 is underrepresented by crop rotation LTFEs, class 3 is underrepresented by fertilization LTFEs and crop rotation LTFEs, class 4 is underrepresented by tillage LTFEs and overrepresented by crop rotation LTFEs (although in number there are only four crop rotation LTFEs), and class 5 again is overrepresented by crop rotation LTFEs (although in number there are only six crop rotation LTFEs) (Table 2; Fig. 4) Overall, the three CWBg classes 1-3 representing $89 \%$ of the arable land area also host $89 \%$ of the LTFEs with a certain bias towards the driest CWBg class 1 . Given that no spatial planning was considered during the allocation of LTFEs, this is a remarkably good distribution.

Among grassland LTFEs, not every CWBg class is represented by LTFEs (Table 3). Thus, CWBg class 6 is present in a small share of grassland $(3 \%)$ but is not represented by 
Table 2. Climatic water balance of the growing season (1 May to 31 October) (CWBg) classification of arable land in Germany and the number and share of the different LTFE types in each CWBg class.

\begin{tabular}{|c|c|c|c|c|c|c|c|c|c|c|c|}
\hline \multirow[t]{2}{*}{$\begin{array}{l}\mathrm{CWBg} \\
\text { class }\end{array}$} & \multirow[t]{2}{*}{$\begin{array}{r}\text { Range } \\
{\left[\mathrm{mm} \mathrm{yr}^{-1}\right]}\end{array}$} & \multicolumn{2}{|c|}{$\begin{array}{l}\text { Agricultural } \\
\text { area (arable) }\end{array}$} & \multicolumn{2}{|c|}{$\begin{array}{l}\text { LTFEs total (arable } \\
\text { land) }(n=169)\end{array}$} & \multicolumn{2}{|c|}{$\begin{array}{c}\text { Fertilization } \\
\text { LTFEs* }^{*}(n=124)\end{array}$} & \multicolumn{2}{|c|}{$\begin{array}{c}\text { Tillage } \\
\text { LTFEs }^{*}(n=38)\end{array}$} & \multicolumn{2}{|c|}{$\begin{array}{c}\text { Crop rotation } \\
\text { LTFEs }^{*}(n=32)\end{array}$} \\
\hline & & $\begin{array}{r}\text { Area } \\
\text { [ha] }\end{array}$ & $\begin{array}{r}\text { Share } \\
{[\%]}\end{array}$ & Number & $\begin{array}{r}\text { Share } \\
{[\%]}\end{array}$ & Number & $\begin{array}{r}\text { Share } \\
{[\%]}\end{array}$ & Number & $\begin{array}{r}\text { Share } \\
{[\%]}\end{array}$ & Number & $\begin{array}{r}\text { Share } \\
{[\%]}\end{array}$ \\
\hline 1 & $<-150$ & 3135676 & 23 & 66 & 39 & 49 & 40 & 13 & 34 & 13 & 41 \\
\hline 2 & -150 to $<-50$ & 4473111 & 33 & 49 & 29 & 39 & 31 & 12 & 32 & 6 & 19 \\
\hline 3 & -50 to $<50$ & 4468852 & 33 & 35 & 21 & 21 & 17 & 11 & 29 & 3 & 9 \\
\hline 4 & 50 to $<150$ & 926798 & 7 & 10 & 6 & 10 & 8 & 1 & 3 & 4 & 13 \\
\hline 5 & 150 to $<300$ & 492110 & 4 & 9 & 5 & 5 & 4 & 1 & 3 & 6 & 19 \\
\hline 6 & 300 to $<500$ & 0 & 0 & 0 & 0 & 0 & 0 & 0 & 0 & 0 & 0 \\
\hline 7 & $>500$ & 0 & 0 & 0 & 0 & 0 & 0 & 0 & 0 & 0 & 0 \\
\hline
\end{tabular}

* Multiple nominations possible.

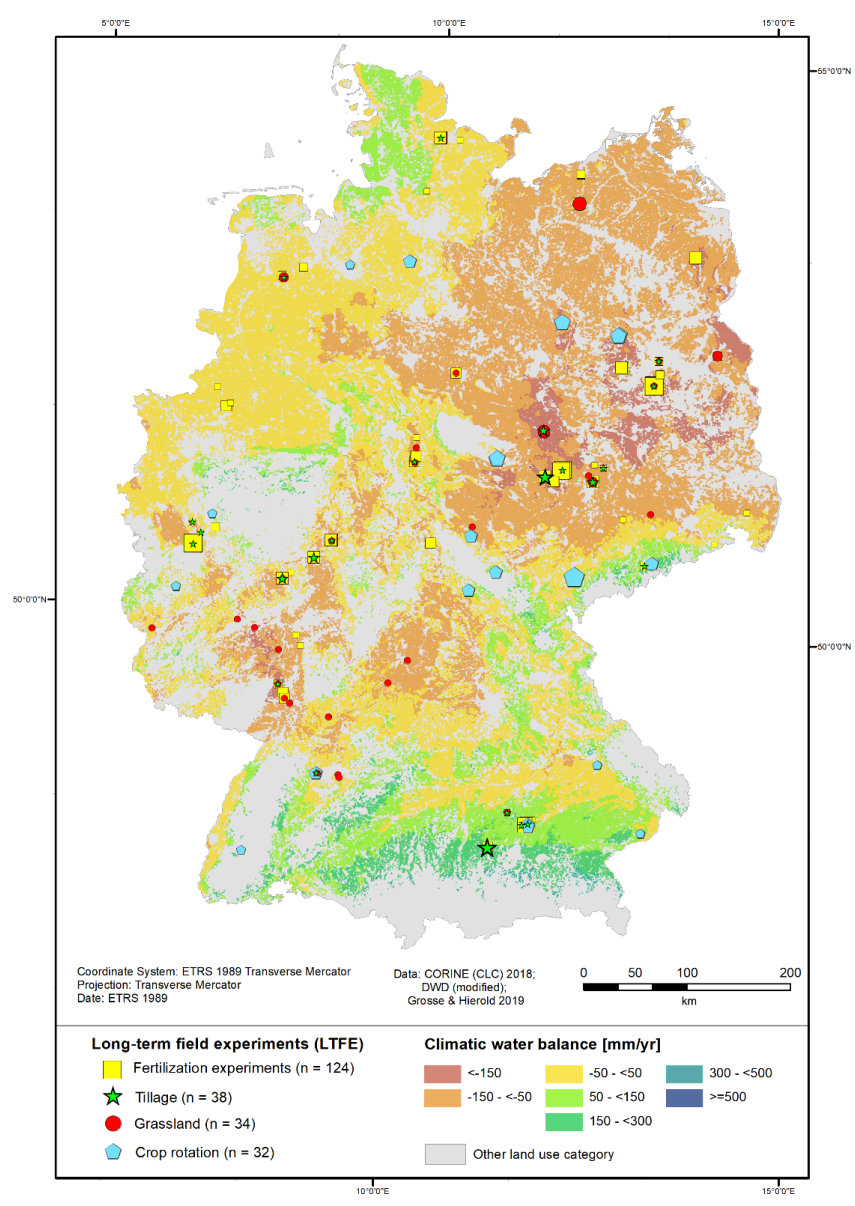

Figure 4. Overview of the distribution of the different climatic water balance classes of the growing season and the different LTFE types in Germany. The size of the symbols varies according to the number of LTFEs at one place.

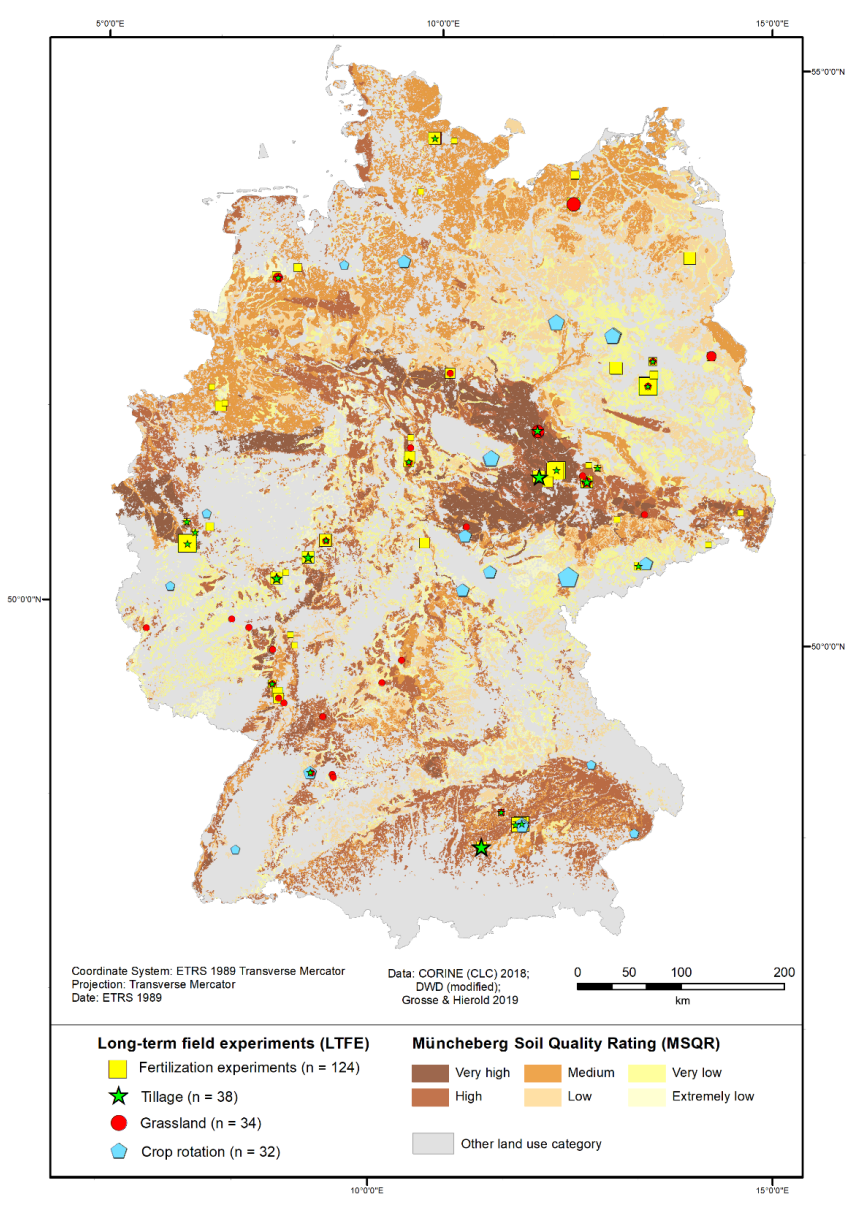

Figure 5. Overview of the distribution of the different Müncheberg Soil Quality Rating classes and the different LTFE types in Germany. The size of the symbols varies according to the number of LTFEs at one place. 
Table 3. Climatic water balance of the growing season $(\mathrm{CWBg})$ classification of agricultural area used for grassland in Germany and the number and share of the LTFEs on grassland in each CWBg class.

\begin{tabular}{|c|c|c|c|c|c|}
\hline \multirow[t]{2}{*}{$\begin{array}{l}\text { CWBg } \\
\text { class }\end{array}$} & \multirow[t]{2}{*}{$\begin{array}{r}\text { Range } \\
{\left[\mathrm{mm} \mathrm{yr}^{-1}\right]}\end{array}$} & \multicolumn{2}{|c|}{$\begin{array}{c}\text { Agricultural } \\
\text { area (grassland) }\end{array}$} & \multicolumn{2}{|c|}{$\begin{array}{c}\text { Grassland } \\
\text { LTFEs }(n=34)\end{array}$} \\
\hline & & $\begin{array}{r}\text { Area } \\
\text { [ha] }\end{array}$ & $\begin{array}{r}\text { Share } \\
{[\%]}\end{array}$ & Number & $\begin{array}{r}\text { Share } \\
{[\%]}\end{array}$ \\
\hline 1 & $<-150$ & 599247 & 14 & 6 & 18 \\
\hline 2 & -150 to $<-50$ & 792064 & 18 & 3 & 9 \\
\hline 3 & -50 to $<50$ & 1420319 & 33 & 15 & 44 \\
\hline 4 & 50 to $<150$ & 398496 & 9 & 7 & 21 \\
\hline 5 & 150 to $<300$ & 1009952 & 23 & 3 & 9 \\
\hline 6 & 300 to $<500$ & 137968 & 3 & 0 & 0 \\
\hline 7 & $>500$ & 0 & 0 & 0 & 0 \\
\hline
\end{tabular}

any grassland LTFEs. CWBg classes 2 and 5 are underrepresented by grassland LTFEs, while CWBg classes 3 and 4 are overrepresented by grassland LTFEs. Overall and compared to the arable land area, the three driest CWBg classes 1-3 represent only $65 \%$ of the grassland area and host $71 \%$ of the grassland LTFEs.

\subsubsection{Geospatial analysis of LTFEs in relation to the Müncheberg Soil Quality Rating (MSQR) distribution}

An overview of the distribution of the MSQR classes and of LTFEs in Germany is given in Fig. 5. Soils classified as "very high" are located mainly in the central part of Germany. Soils classified as "high" exist in the central part and in the south of Germany as well as in some smaller areas in the northwestern region of Germany, including the coastlines. Soils classified as "low" and "medium" are predominant in the northern part of Germany but also exist in some areas in the middle and south of Germany. Soils classified as "very low" mainly exist in northeastern Germany. Soils classified as "extremely low" exist mainly in small areas of mid-east, mid-west and northwest Germany (Fig. 5).

The classification of the agricultural area into the six MSQR classes (Table 4) is as follows: the largest share $(28 \%)$ of agricultural area is classified as medium. The smallest shares are classified as extremely low (6\%) and very high $(10 \%)$. Medium shares are classified as very low $(17 \%)$, low (21\%) and high (18\%). LTFE sites exist in all MSQR classes, and overall, the distribution of the LTFE sites follows a similar pattern as that of the MSQR classes, with the exception of a bias towards the high MSQR class.

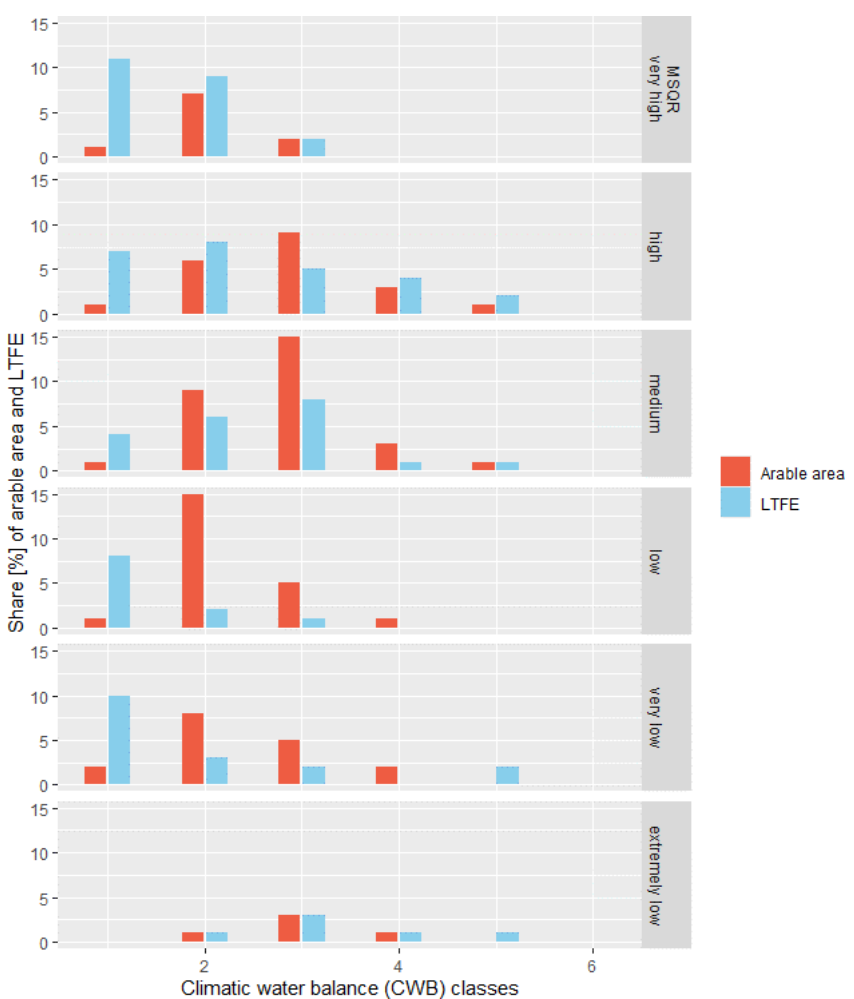

Figure 6. Share of arable area and LTFEs in every climatic water balance and Müncheberg Soil Quality Rating combination.

\subsubsection{Geospatial analysis of LTFEs in relation to the combined CWBg and MSQR distribution}

The share of the arable area in Germany and the share of LTFEs on arable land in every CWBg-MSQR intersection are compared (Fig. 6). According to this analysis, in the MSQR class extremely low, the share of LTFEs matches the share of arable land area in each CWBg class. In the other MSQR classes, CWBg class 1 is overrepresented by LTFEs compared to the respective land area. Thus, regarding climate, the distribution of LTFEs is biased towards dry areas with the very low CWBg class 1 . The reason for this bias is probably because most of these LTFEs are located in the region surrounding Berlin and the region Bad LauchstädtHalle-Seehausen, which are both historical agricultural research areas.

In CWBg class 2, the distribution of LTFEs is biased towards high and very high MSQR classes. This result is mainly caused by the sites Bonn, Braunschweig, Gießen and Göttingen.

CWBg class 3 is underrepresented by LTFEs in the MSQR classes of very low, low, medium and high.

$\mathrm{CWBg}$ classes 4 and 5 are rather adequately represented by LTFEs in every MSQR class. However, these CWBg classes rarely exist in Germany.

For the landscape approach proposed in this paper, more LTFEs would be required in areas with CWBg class 3 on 
Table 4. Müncheberg Soil Quality Rating (MSQR) classification of arable land in Germany and the number and share of the different LTFE types in each MSQR class.

\begin{tabular}{lrr|rr|rr|rr|r}
\hline MSQR & \multicolumn{2}{c}{$\begin{array}{c}\text { Agricultural } \\
\text { area }\end{array}$} & $\begin{array}{c}\text { LTFEs total (arable } \\
\text { land) }(n=169)\end{array}$ & $\begin{array}{r}\text { Fertilization } \\
\text { LTFEs* }^{*}(n=123)\end{array}$ & $\begin{array}{r}\text { Tillage } \\
\text { LTFEs* }^{*}(n=38)\end{array}$ & $\begin{array}{c}\text { Crop rotation } \\
\text { LTFEs* }(n=32)\end{array}$ \\
\cline { 2 - 9 } & $\begin{array}{r}\text { Area } \\
{[\text { ha] }}\end{array}$ & $\begin{array}{r}\text { Share } \\
{[\%]}\end{array}$ & Number & $\begin{array}{r}\text { Share } \\
{[\%]}\end{array}$ & Number & $\begin{array}{r}\text { Share } \\
{[\%]}\end{array}$ & $\begin{array}{r}\text { Number } \\
\text { Share } \\
{[\%]}\end{array}$ & $\begin{array}{r}\text { Number } \\
\text { Share } \\
{[\%]}\end{array}$ \\
\hline Extremely low & 705687 & 6 & 9 & 5 & 5 & 4 & 4 & 11 & 3 \\
Very low & 2149584 & 17 & 29 & 17 & 22 & 18 & 5 & 13 & 5 \\
Low & 2656535 & 21 & 18 & 11 & 13 & 11 & 3 & 8 & 1 \\
Medium & 3532109 & 28 & 32 & 19 & 28 & 23 & 6 & 16 & 4 \\
High & 2182221 & 18 & 45 & 27 & 28 & 23 & 13 & 34 & 11 \\
Very high & 1181237 & 10 & 36 & 21 & 27 & 22 & 7 & 18 & 8 \\
\hline
\end{tabular}

* Multiple nominations possible.

Table 5. Clay content classification according to ESDAC (2020) of arable land in Germany and the number and share of the different LTFE types in each clay content class.

\begin{tabular}{|c|c|c|c|c|c|c|c|c|c|c|c|}
\hline \multirow[t]{2}{*}{$\begin{array}{l}\text { Clay content } \\
\text { class }\end{array}$} & \multirow[t]{2}{*}{$\begin{array}{r}\text { Range } \\
{[\%]}\end{array}$} & \multicolumn{2}{|c|}{$\begin{array}{l}\text { Agricultural } \\
\text { area (arable) }\end{array}$} & \multicolumn{2}{|c|}{$\begin{array}{l}\text { LTFEs total (arable } \\
\text { land) }(n=169)\end{array}$} & \multicolumn{2}{|c|}{$\begin{array}{c}\text { Fertilization } \\
\text { LTFEs* }^{*}(n=124)\end{array}$} & \multicolumn{2}{|c|}{$\begin{array}{c}\text { Tillage } \\
\text { LTFEs* }(n=38)\end{array}$} & \multicolumn{2}{|c|}{$\begin{array}{c}\text { Crop rotation } \\
\text { LTFEs* }^{*}(n=32)\end{array}$} \\
\hline & & $\begin{array}{r}\text { Area } \\
{[\mathrm{ha}]}\end{array}$ & $\begin{array}{r}\text { Share } \\
{[\%]}\end{array}$ & Number & $\begin{array}{r}\text { Share } \\
{[\%]}\end{array}$ & Number & $\begin{array}{r}\text { Share } \\
{[\%]}\end{array}$ & Number & $\begin{array}{r}\text { Share } \\
{[\%]}\end{array}$ & Number & $\begin{array}{r}\text { Share } \\
{[\%]}\end{array}$ \\
\hline 1 & 0 to 5 & 1748393 & 14 & 25 & 15 & 19 & 15 & 6 & 16 & 3 & 9 \\
\hline 2 & 6 to 10 & 2404798 & 19 & 24 & 14 & 19 & 15 & 6 & 16 & 3 & 9 \\
\hline 3 & 11 to 16 & 2265517 & 18 & 29 & 17 & 20 & 16 & 5 & 13 & 4 & 13 \\
\hline 4 & 17 to 19 & 1523493 & 12 & 42 & 25 & 37 & 30 & 6 & 16 & 6 & 19 \\
\hline 5 & 20 to 21 & 1179602 & 9 & 15 & 9 & 12 & 10 & 2 & 5 & 8 & 25 \\
\hline 6 & 22 to 24 & 1553463 & 12 & 20 & 12 & 11 & 9 & 5 & 13 & 6 & 19 \\
\hline 7 & 25 to 27 & 1097725 & 9 & 4 & 2 & 1 & 1 & 3 & 8 & 1 & 3 \\
\hline 8 & 28 to 98 & 1082066 & 8 & 10 & 6 & 5 & 4 & 5 & 13 & 1 & 3 \\
\hline
\end{tabular}

Table 6. Clay content classification according to ESDAC (2020) of agricultural area used for grassland in Germany and the number and share of the LTFEs on grassland in each clay content class.

\begin{tabular}{lrrr|rr}
\hline $\begin{array}{l}\text { Clay con- } \\
\text { tent class }\end{array}$ & $\begin{array}{r}\text { Range } \\
{[\%]}\end{array}$ & $\begin{array}{r}\text { Agricultural area } \\
\text { (grassland) }\end{array}$ & \multicolumn{2}{c}{$\begin{array}{c}\text { Grassland } \\
\text { LTFEs }(n=34)\end{array}$} \\
\cline { 3 - 6 } & & $\begin{array}{r}\text { Area } \\
\text { [ha] }\end{array}$ & $\begin{array}{r}\text { Share } \\
{[\%]}\end{array}$ & Number & $\begin{array}{r}\text { Share } \\
{[\%]}\end{array}$ \\
\hline 1 & & 715137 & 11 & 3 & 9 \\
2 & 0 to 5 & 15 & 5 & 15 \\
3 & 6 to 10 & 941166 & 15 & 0 & 0 \\
4 & 11 to 16 & 952126 & 15 & 4 & 12 \\
5 & 17 to 19 & 821432 & 13 & 6 & 18 \\
6 & 20 to 21 & 710826 & 11 & 5 & 15 \\
7 & 22 to 24 & 978366 & 15 & 8 & 24 \\
8 & 25 to 27 & 651066 & 10 & 3 & 9 \\
\hline
\end{tabular}

soils classified as MSQR very low, low, medium and high and in areas with CWBg class 2 on soils classified as MSQR classes very low, low and medium.

\subsubsection{Geospatial analysis of LTFE in relation to the clay content distribution}

According to Table 5, every clay content class is represented by LTFEs on arable land. Clay content class 4 (17\% to $19 \%$ clay content) is overrepresented by LTFE, while the high clay content classes 7 ( $25 \%$ to $27 \%$ clay content) and 8 ( $28 \%$ to $98 \%$ clay content) are underrepresented, especially by fertilization and crop rotation LTFEs.

Among grassland, LTFEs in clay content class 3 (11\% to $16 \%$ clay content) are completely missing (Table 6$)$. The clay content classes 5 (20\% to $21 \%$ clay content), 6 ( $22 \%$ to $24 \%$ clay content) and 7 (25\% to $27 \%$ clay content) are overrepresented by grassland LTFEs, while the other clay content classes are rather equally represented.

Franko et al. (2011) found in their analysis of 40 LTFEs for the validation of a simplified carbon balance model, derived from the CANDY model, that more experimental results on clay soils would be required. This could be confirmed for LTFEs on arable land in this study. 


\section{Conclusions}

To obtain adequate information about each CWBg, MSQR and clay content class through LTFEs, more LTFEs would have to be established. However, nearly every class is represented by at least some LTFEs. For the joint analysis, there are other more important constraints: data are not easy to access, and sometimes the older data are not digitized. Here, BonaRes offers great opportunities through the provision of support for data preparation and through the establishment of a common database. We hope that this great opportunity will be frequently used by LTFE holders in future. 


\section{Appendix A}

Table A1. IDs of all long-term field experiments, their original name, their location, their CWBg class (1 May to 31 October), their MSQR class and their thematic classification. The institution address is indicated by a number and given below the table. More details about the LTFEs can be found in the complete dataset (Grosse and Hierold, 2019).

\begin{tabular}{|c|c|c|c|c|c|c|}
\hline ID & LTFE name & Place of LTFE & $\begin{array}{r}\text { Address } \\
\text { (see below) }\end{array}$ & $\begin{array}{r}\text { CWBg } \\
\text { class }\end{array}$ & $\begin{array}{l}\text { MSQR } \\
\text { class }\end{array}$ & $\begin{array}{l}\text { Thematic } \\
\text { classification }\end{array}$ \\
\hline \multicolumn{7}{|c|}{ Field crop LTFE } \\
\hline 1 & Bodenbearbeitungsversuch Dichtelbach & Dichtelbach (Hunsrück) & 1 & 3 & very low & Tillage \\
\hline 2 & Bodenbearbeitungsversuch Welschbillig & Welschbillig (Eifel) & 1 & 3 & very low & Tillage \\
\hline 3 & Bodenbearbeitungsversuch Wintersheim & Wintersheim (Rheinhessen) & 1 & 1 & very high & Tillage \\
\hline 4 & Statischer Düngungsversuch V120 & Bad Lauchstädt & 2 & 1 & very high & Fertilization \\
\hline 5 & Erweiterter Statischer Düngungsversuch V120a & Bad Lauchstädt & 2 & 1 & very high & Fertilization \\
\hline 6 & Modellversuch Stalldungsteigerung & Bad Lauchstädt & 2 & 1 & very high & Fertilization \\
\hline 7 & Bracheversuch V505a & Bad Lauchstädt & 2 & 1 & very high & Other \\
\hline 8 & Statischer Stickstoffdüngungsversuch & Bad Salzungen & 3 & 2 & very low & Fertilization \\
\hline 9 & Statischer Kalkdüngungsversuch M16 & Bad Salzungen & 3 & 2 & very low & Fertilization \\
\hline 11 & Dauerdüngungsversuch L28 & Bad Salzungen & 3 & 2 & very low & Fertilization \\
\hline 13 & Statischer Dauerversuch Bodennutzung (BDa_D3) & Berlin-Dahlem & 4 & 1 & very low & Fertilization/Tillage/Crop rotation \\
\hline 14 & $\begin{array}{l}\text { Internationaler Organischer-Stickstoff-Dauerdüngungsversuch } \\
\text { (BDa_IOSDV) }\end{array}$ & Berlin-Dahlem & 4 & 1 & very low & Fertilization \\
\hline 15 & Agrarmeteorologisches Intensivmessfeld (BDa_E-Feld) & Berlin-Dahlem & 4 & 1 & very low & Other \\
\hline 16 & Bodenbearbeitungsversuch (Versuchsfeld Westerfeld) & Bernburg-Strenzfeld & 5 & 1 & very high & Tillage \\
\hline 17 & Anbausysteme-Vergleich & Bernburg-Strenzfeld & 6 & 1 & very high & Crop rotation/Other \\
\hline 18 & $\begin{array}{l}\text { Grundbodenbearbeitung und Distelbekämpfung, ökologisch } \\
\text { viehlos }\end{array}$ & Bernburg-Strenzfeld & 6 & 1 & very high & Tillage/Crop rotation/Other \\
\hline 19 & Bodenbearbeitung und Bestelltechnik in der Fruchtfolge & Bernburg-Strenzfeld & 6 & 1 & very high & Tillage/Other \\
\hline 20 & Dauerdüngungsversuch Dikopshof & Wesseling-Dikopshof & 7 & 2 & very high & Fertilization/Crop rotation \\
\hline 21 & Selektions-Dauerversuch SDV & Klein Altendorf & 7 & 3 & very high & Crop rotation \\
\hline 22 & Strohdüngung zu Getreide & Meckenheim & 7 & 2 & very high & Fertilization \\
\hline 23 & Phosphatformenversuch & Meckenheim & 7 & 2 & very high & Fertilization \\
\hline 24 & Organische Düngung & Meckenheim & 7 & 2 & very high & Fertilization \\
\hline 25 & Strohdüngung mit Faulschlamm & Meckenheim & 7 & 2 & very high & Fertilization \\
\hline 26 & Kaliformenversuch & Meckenheim & 7 & 2 & very high & Fertilization \\
\hline 27 & Strohdüngung mit verschiedenen N-Formen & Meckenheim & 7 & 2 & very high & Fertilization \\
\hline 28 & Phosphatvorratsdüngung & Meckenheim & 7 & 2 & very high & Fertilization \\
\hline 29 & Kalkversuch mit Spurenelementen & Meckenheim & 7 & 2 & very high & Fertilization \\
\hline 30 & Versuch mit Faulschlämmen & Meckenheim & 7 & 2 & very high & Fertilization \\
\hline 31 & Dauerdüngungsversuch & Bonn-Poppelsdorf & 7 & 2 & high & Fertilization/Crop rotation \\
\hline 33 & Langzeit Düngungsversuch (FV4) & Völkenrode & 8 & 2 & very high & Fertilization/Tillage \\
\hline 34 & C-Dauerfeldversuch (FV36) & Völkenrode & 8 & 2 & very high & Fertilization \\
\hline 35 & Südfeld-Düngungsversuch & Völkenrode & 9 & 2 & very high & Fertilization \\
\hline 36 & $\begin{array}{l}\text { Folgenabschätzung der Wechselwirkung von Fruchtfolge, Dün- } \\
\text { gung und Pflanzenschutz }\end{array}$ & Dahnsdorf & 10 & 1 & high & Other \\
\hline 37 & Langzeit-Düngungsversuch & Darmstadt & 11 & 2 & low & Fertilization \\
\hline 38 & Klassischer DFV (4b2, organische und mineralische Düngung) & Dülmen & 12 & 3 & medium & Fertilization \\
\hline 39 & Dauerdüngungsversuch IOSDV & Dülmen & 12 & 3 & medium & Fertilization \\
\hline 40 & Zuckerrübenfruchtfolgeversuch & Etzdorf & 13 & 1 & very high & Fertilization/Crop rotation/Other \\
\hline 41 & Dauerdüngungsversuch (Zuckerrübenmonokultur) & Etzdorf & 13 & 1 & very high & Fertilization/Crop rotation \\
\hline 42 & Dauerdüngungsversuch Getreide (Getreidedauerversucht) & Etzdorf & 13 & 1 & very high & Fertilization/Crop rotation \\
\hline 43 & $\begin{array}{l}\text { Dauerdüngungsversuch Getreide (Getreidedauerversuch zur } \\
\text { Bekämpfung der Halmbruchkrankheit) }\end{array}$ & Etzdorf & 13 & 1 & very high & Fertilization/Crop rotation \\
\hline 44 & N-Formen-Versuch & Freising & 14 & 4 & high & Fertilization/Crop rotation \\
\hline 45 & P-Düngung & Freising & 14 & 4 & high & Fertilization \\
\hline 47 & Stroh/Stalldung-Fruchtfolge & Freising & 14 & 4 & high & Fertilization \\
\hline 48 & N-Düngung/Fruchtfolge & Freising & 14 & 4 & high & Fertilization \\
\hline 49 & N-Steigerung mit Kalkstickstoff & Freising & 14 & 4 & high & Fertilization \\
\hline 50 & Versuch $020 \mathrm{~N}$-Formen-Versuch & Freising & 14 & 3 & high & Fertilization \\
\hline 51 & Bodenbearbeitungsversuch Südzucker & Friemar & 15 & 2 & very high & Tillage \\
\hline 52 & Erschöpfungsversuch (EV) & Gießen & 16 & 2 & low & Fertilization \\
\hline 53 & Kalkdüngungsversuch & Gießen & 16 & 2 & high & Fertilization \\
\hline 54 & Dauerversuch Biologische Stickstofffixierung (BSG) & Gießen & 16 & 2 & high & Fertilization/Crop rotation \\
\hline 55 & Ökologischer Ackerbauversuch Gladbacherhof & Villmar & 17 & 2 & extremely low & Fertilization/Tillage/Crop rotation \\
\hline 56 & Bodenbearbeitungsversuch Hohes Feld & Nörten-Hardenberg & 18 & 3 & high & Tillage \\
\hline 57 & Garte-Süd-Bodenbearbeitung (Reinshof) & Göttingen & 18 & 2 & very high & Tillage \\
\hline 58 & Garte-Nord-Bodenbearbeitung (Reinshof) & Göttingen & 18 & 2 & high & Crop rotation \\
\hline 59 & Langzeitversuch zur P- und K-Düngung auf dem Reinshof & Nörten-Hardenberg & 19 & 2 & high & Fertilization \\
\hline 60 & Bodenbearbeitungsversuch Südzucker & Grombach & 15 & 3 & high & Tillage \\
\hline 61 & Kastenparzellenversuch Sandboden / Lehmboden / Tonboden & Großbeeren & 20 & 1 & & Fertilization \\
\hline
\end{tabular}


Table A1. Continued.

\begin{tabular}{|c|c|c|c|c|c|c|}
\hline ID & LTFE name & Place of LTFE & $\begin{array}{r}\text { Address } \\
\text { (see below) }\end{array}$ & $\begin{array}{r}\text { CWBg } \\
\text { class }\end{array}$ & $\begin{array}{l}\text { MSQR } \\
\text { class }\end{array}$ & $\begin{array}{l}\text { Thematic } \\
\text { classification }\end{array}$ \\
\hline 62 & PK-Mangelversuch & Groß Gerau & 16 & 1 & very low & Fertilization \\
\hline 63 & Dauerfeldversuch P60 & Groß Kreutz & 21 & 1 & low & Fertilization \\
\hline 64 & Dauerfeldversuch M4 & Groß Kreutz & 21 & 1 & very low & Fertilization \\
\hline 65 & Versuchsfeld der Versuchsstation Groß Lüsewitz & Groß Lüsewitz & 22 & 2 & very low & Other \\
\hline 66 & Ewiger Roggen & Halle & 23 & 1 & medium & Fertilization/Crop rotation \\
\hline 67 & Schmalfuss'scher Dauerversuch, Feld A, Kalkdüngung & Halle & 23 & 1 & very high & Fertilization \\
\hline 68 & Schmalfuss'scher Dauerversuch, Feld C, Kaliumdüngung & Halle & 23 & 1 & very high & Fertilization \\
\hline 69 & Schmalfuss'scher Dauerversuch, Feld D, Phosphordüngung & Halle & 23 & 1 & very high & Fertilization \\
\hline 70 & Organische Düngung (Feld F) & Halle & 23 & 1 & very high & Fertilization \\
\hline 71 & Dauerfeldversuch "Bodenfruchtbarkeit" & Hennef & 7 & 3 & very high & Fertilization \\
\hline 72 & Dauerversuch Düngung-Fruchtfolge & Renningen & 24 & 4 & medium & Fertilization/Crop rotation \\
\hline 73 & Versuch zur Bodenbearbeitung & Renningen & 24 & 3 & low & Tillage \\
\hline 74 & Dauerdüngungsversuch & Hohenschulen & 25 & 3 & high & Fertilization \\
\hline 75 & Stickstoffversuch "Decline-Versuch" & Hohenschulen & 25 & 3 & medium & Fertilization \\
\hline 76 & Fruchtfolgeversuch & Hohenschulen & 25 & 3 & medium & Fertilization/Crop rotation \\
\hline 77 & N-Düngung zu Wintergerste & Hohenschulen & 25 & 3 & medium & Fertilization \\
\hline 78 & Düngerartenvergleich (Versuch I) & Lauterbach & 23 & 5 & medium & Fertilization/Crop rotation \\
\hline 79 & Kombinationswirkung (Versuch II) & Lauterbach & 23 & 5 & very low & Fertilization \\
\hline 80 & Nährstoffverhältnisversuch & Limburgerhof/Bruch & 26 & 1 & very low & Fertilization \\
\hline 81 & Feldwirtschaftsversuch & Limburgerhof/Bruch & 26 & 1 & low & Fertilization \\
\hline 82 & Nährstoffmangelversuch & Limburgerhof & 26 & 1 & low & Fertilization \\
\hline 83 & WW-Fruchtfolgeversuch & Ludwigshafen/Ruchheim & 26 & 1 & low & Fertilization/Crop rotation/Other \\
\hline 84 & Bodenbearbeitungsversuch & Ludwigshafen/Ruchheim & 26 & 1 & high & Fertilization/Tillage \\
\hline 85 & Bodenbearbeitungsversuch & Lüttewitz & 15 & 2 & high & Tillage \\
\hline 86 & Dauerdüngungsversuch L28 & Methau & 27 & 3 & high & Fertilization \\
\hline 87 & Dauerdüngungsversuch (V140) & Müncheberg & 28 & 1 & low & Fertilization \\
\hline 88 & Bodenbearbeitung (V760) & Müncheberg & 28 & 1 & low & Tillage \\
\hline 89 & Modellbetrieb Organischer Landbau, Felder 931-934 & Müncheberg & 28 & 1 & low & Other \\
\hline 90 & Kalium-Steigerungsversuch Höckelheim/Südniedersachsen & Northeim/Höckelheim & 29 & 2 & low & Fertilization \\
\hline 91 & P-Düngung auf Sandmischkultur & Oldenburg/Friesoythe & 29 & 3 & medium & Fertilization \\
\hline 92 & Bodenbearbeitung/Fruchtfolge & Oldenburg/Friesoythe & 18 & 3 & extremely low & Tillage/Crop rotation \\
\hline 93 & Bodenbearbeitung & Oldenburg/Friesoythe & 18 & 3 & extremely low & Tillage \\
\hline 94 & $\begin{array}{l}\text { Internationaler Organischer Stickstoffdüngungs-Versuch } \\
\text { (IOSDV) }\end{array}$ & Oldenburg & 30 & 3 & extremely low & Fertilization \\
\hline 96 & Dauerversuch "Auswirkung von Daueranbau" & Puch & 31 & 5 & extremely low & Crop rotation \\
\hline 97 & Verbesserte Dreifelderwirtschaft & Puch & 31 & 5 & high & Crop rotation \\
\hline 98 & Getreide/Mais Fruchtfolge & Puch & 31 & 5 & high & Crop rotation \\
\hline 99 & Einfluss von Grundbodenbearbeitung & Puch & 31 & 5 & high & Tillage \\
\hline 100 & $\begin{array}{l}\text { Internationaler Organischer Stickstoffdüngungs-Versuch } \\
\text { (IOSDV) }\end{array}$ & Puch & 31 & 5 & high & Fertilization \\
\hline 101 & $\begin{array}{l}\text { Internationaler Organischer Stickstoffdüngungs-Versuch } \\
\text { (IOSDV) }\end{array}$ & Rauischholzhausen & 16 & 2 & high & Fertilization \\
\hline 102 & Organische Düngung / Stalldung Schafpferchversuch & Rauischholzhausen & 16 & 2 & high & Fertilization \\
\hline 103 & Gründüngung / Strohdüngungsversuch & Rauischholzhausen & 16 & 2 & high & Fertilization \\
\hline 104 & Bilanzversuch Kastenanlage & Rauischholzhausen & 16 & 2 & high & Fertilization \\
\hline 105 & $\begin{array}{l}\text { Wirkungen differenzierter Bodenbearbeitungssysteme im } \\
\text { Dauerversuch Scheyern }\end{array}$ & Scheyern & 32 & 4 & high & Fertilization/Tillage/Crop rotation \\
\hline 106 & Fruchtfolgedüngungsversuch & Seehausen & 23 & 1 & high & Fertilization/Crop rotation \\
\hline 107 & Konzentrationsversuch & Seehausen & 23 & 1 & high & Crop rotation \\
\hline 108 & Düngungs-Kombinationsversuch Seehausen (F1-70) & Seehausen & 23 & 1 & high & Fertilization \\
\hline 109 & Bodenbearbeitungsversuch & Seehausen & 23 & 1 & high & Tillage \\
\hline 110 & Gülledauerversuch & Seehausen & 23 & 1 & high & Fertilization \\
\hline 111 & Bodenfruchtbarkeitsversuch & Seehausen & 23 & 1 & high & Fertilization/Tillage \\
\hline 112 & $\begin{array}{l}\text { Internationaler Organischer Stickstoffdüngungs-Versuch } \\
\text { (IOSDV) }\end{array}$ & Speyer & 33 & 2 & high & Fertilization/Tillage \\
\hline 113 & Humusversuch & Speyer & 33 & 2 & medium & Fertilization/Other \\
\hline 114 & Kali-Magnesium-Kalk-Versuch & Speyer & 33 & 2 & medium & Fertilization \\
\hline 115 & Klärschlammversuch & Speyer & 33 & 2 & medium & Other \\
\hline 116 & Bracheversuch & Speyer & 33 & 2 & medium & Other \\
\hline 117 & Dauerdüngungsversuch L28 & Spröda & 27 & 1 & medium & Fertilization \\
\hline 119 & Düngungs- und Beregnungsversuch (Thy_D1) & Thyrow & 34 & 1 & high & Fertilization/Other \\
\hline 120 & $\begin{array}{l}\text { Stroh- und N-Düngung in Fruchtfolgen mit unterschiedlichem } \\
\text { Getreideanteil (Thy_D5) }\end{array}$ & Thyrow & 34 & 1 & very low & Fertilization/Crop rotation \\
\hline 121 & Statischer Nährstoffmangelversuch (Thy_D41) & Thyrow & 34 & 1 & very low & Fertilization \\
\hline 122 & Nährstoffmangelversuch Winterroggen Monokultur (Thy_D42) & Thyrow & 34 & 1 & very low & Fertilization \\
\hline 123 & Statischer Bodenfruchtbarkeitsversuch (Thy_D6) & Thyrow & 34 & 1 & very low & Fertilization \\
\hline 125 & Strohdüngungsversuch (Thy_D2) & Thyrow & 34 & 1 & very low & Fertilization \\
\hline 136 & Modellbetrieb Organischer Landbau, Felder 901-904 & Müncheberg & 28 & 1 & very low & Other \\
\hline 137 & $\begin{array}{l}\text { Statischer Dauerfeldversuch "organisch-mineralische } \\
\text { N-Düngung" }\end{array}$ & Großbeeren & 20 & 1 & very low & Fertilization \\
\hline 138 & Versuch zur Bodenbearbeitung & Schönberg & 35 & 3 & low & Tillage \\
\hline 139 & Gehölzhäckselapplikation & Schönberg & 35 & 3 & very low & Other \\
\hline 140 & Versuch 700 (Reduzierte Bodenbearbeitung) & Schönberg & 35 & 3 & extremely low & Tillage \\
\hline
\end{tabular}


Table A1. Continued.

\begin{tabular}{|c|c|c|c|c|c|c|}
\hline ID & LTFE name & Place of LTFE & $\begin{array}{r}\text { Address } \\
\text { (see below) }\end{array}$ & $\begin{array}{r}\mathrm{CWBg} \\
\text { class }\end{array}$ & $\begin{array}{l}\text { MSQR } \\
\text { class }\end{array}$ & $\begin{array}{l}\text { Thematic } \\
\text { classification }\end{array}$ \\
\hline 142 & Effiziente Nährstoffverwertung, K-Eichversuche & Pommritz & 27 & 2 & extremely low & Fertilization \\
\hline 143 & Effiziente Nährstoffverwertung, K-Eichversuche & Forchheim & 27 & 4 & extremely low & Fertilization \\
\hline 144 & Referenzfläche & Hennef & 7 & 3 & medium & Fertilization \\
\hline 146 & Statischer Versuch Bodennutzung (Thy_D3/1) & Thyrow & 34 & 1 & very low & Fertilization/Tillage \\
\hline 147 & $\begin{array}{l}\text { Statischer Dauerfeldversuch Organische Düngung und Humus- } \\
\text { reproduktion (Thy_D3/2) }\end{array}$ & Thyrow & 34 & 1 & medium & Fertilization \\
\hline 148 & $\begin{array}{l}\text { Statischer N-Düngungsversuch in Winterroggen-Monokultur } \\
\text { (Thy_D7) }\end{array}$ & Thyrow & 34 & 1 & very low & Fertilization \\
\hline 149 & Alte dreifeldrige Fruchtfolge & Puch & 31 & 5 & very low & Fertilization/Crop rotation \\
\hline 150 & Fruchtfolgen im ökologischen Landbau & Puch & 31 & 5 & very low & Fertilization/Crop rotation \\
\hline 151 & Fruchtfolgen im ökologischen Landbau & Viehhausen & 31 & 4 & high & Fertilization/Crop rotation \\
\hline 152 & Fruchtfolgeversuch (FF) & Rauischholzhausen & 16 & 2 & high & Crop rotation \\
\hline 153 & Bodenbearbeitungs-Versuch (BB) & Rauischholzhausen & 16 & 3 & high & Tillage \\
\hline 154 & Bodenbearbeitungsversuch Südzucker & Zschortau & 15 & 1 & high & Tillage \\
\hline 155 & Bodenbearbeitungsversuch Südzucker & Insultheim & 15 & 2 & high & Tillage \\
\hline 156 & Bodenbearbeitungsversuch Südzucker & Sailtheim & 15 & 3 & high & Tillage \\
\hline 157 & Bodenbearbeitungsversuch Südzucker & Gieshügel & 15 & 2 & medium & Tillage \\
\hline 158 & Strategievergleich umweltschonender Pflanzenschutz (BS1) & Dahnsdorf & 10 & 1 & low & Other \\
\hline 159 & Ökologischer Landbau (öko1) & Dahnsdorf & 10 & 1 & high & Other \\
\hline 160 & $\begin{array}{l}\text { Strategien zur Minderung der Anwendung chemischer } \\
\text { Pflanzenschutzmittel (BS4) }\end{array}$ & Dahnsdorf & 10 & 1 & high & Other \\
\hline 161 & Kalk-Düngungsversuch & Weilmünster-Ernsthausen & 36 & 3 & high & Fertilization \\
\hline 162 & Phosphordüngungsstrategien & Biestow & 37 & 2 & high & Fertilization \\
\hline 165 & Körnermais Daueranbau & Rotthalmünster & 38 & 3 & extremely low & Fertilization \\
\hline 166 & Winterweizen Daueranbau & Rotthalmünster & 38 & 3 & medium & Other \\
\hline 167 & E-Feld (bis 1957) & Göttingen & 18 & 3 & medium & Fertilization \\
\hline 193 & Dauerfeldversuch (DE-1b-F-1, Am Kotten) & Rosendahl Holtwick & 12 & 3 & medium & Fertilization \\
\hline 194 & Dauerfeldversuch (DE-1b-F-2, Am Hof) & Dülmen Karthaus & 12 & 3 & no data & Fertilization \\
\hline 195 & Dauerfeldversuch (DE-1b-F-3, IPU Schlag 9) & Dülmen & 12 & 3 & medium & Fertilization \\
\hline 197 & Feldmodellversuch "Krumenaufbau" & Müncheberg & 28 & 1 & medium & Fertilization/Tillage \\
\hline 203 & Kalkformenversuch & Cunnersdorf & 39 & 3 & medium & Fertilization \\
\hline 205 & Dauerdüngungsversuch (M70) & Groß Kreuz & 40 & 1 & low & Fertilization \\
\hline 206 & Getreidedauerversuch & Noitzsch & 13 & 1 & very low & Fertilization/Crop rotation/Other \\
\hline 207 & Stroh-Stallmistversuch & Lentföhrden & 25 & 3 & very low & Fertilization \\
\hline 208 & Phosphor-Steigerungsversuch & Schädtbek & 25 & 2 & very low & Fertilization \\
\hline 209 & $\begin{array}{l}\text { Fruchtfolgeversuch Bodenbearbeitung/organische Düngung } \\
\text { Winterraps (FF 1.1) }\end{array}$ & Gülzow & 41 & 2 & medium & Fertilization/Tillage \\
\hline 210 & $\begin{array}{l}\text { Fruchtfolgeversuch Bodenbearbeitung/organische Düngung } \\
\text { Sommerweizen (FF 1.2) }\end{array}$ & Gülzow & 41 & 2 & medium & Fertilization/Tillage \\
\hline 211 & $\begin{array}{l}\text { Fruchtfolgeversuch Bodenbearbeitung/organische Düngung } \\
\text { Winterweizen (FF 2.1) }\end{array}$ & Gülzow & 41 & 2 & medium & Fertilization/Tillage \\
\hline 212 & $\begin{array}{l}\text { Fruchtfolgeversuch Bodenbearbeitung/organische Düngung } \\
\text { Silomais (FF 2.2) }\end{array}$ & Gülzow & 41 & 2 & medium & Fertilization/Tillage \\
\hline 213 & $\begin{array}{l}\text { Schmalfuss'scher Dauerversuch, Feld B (physiologischen } \\
\text { Reaktion von Düngemitteln) }\end{array}$ & Halle & 23 & 1 & medium & Fertilization \\
\hline 214 & Schmalfuss'scher Dauerversuch, Feld E, Stickstoffdüngung & Halle & 23 & 1 & medium & Fertilization \\
\hline 217 & E-Feld (ab 1957) & Göttingen & 18 & 3 & very high & Fertilization \\
\hline 218 & Modellversuch zur Bodenbildung & Halle & 23 & 1 & very high & Fertilization \\
\hline 219 & Weihenstephaner Kali-Formenversuch & Weihenstephan & 30 & 4 & no data & Fertilization \\
\hline 220 & Kleinparzellenversuch Hu1 bzw. Hu1To9 & Rostock & 37 & 2 & no data & Fertilization \\
\hline 221 & Organische Düngestoffe - Wirkung (V140/06) & Dedelow & 28 & 1 & low & Fertilization \\
\hline 222 & Organische Düngestoffe - Wirkung (V140/07) & Dedelow & 28 & 1 & low & Fertilization \\
\hline 223 & Organische Düngestoffe - Wirkung (V140/08) & Dedelow & 28 & 1 & low & Fertilization \\
\hline 224 & Organische Düngestoffe - Wirkung (V140/09) & Dedelow & 28 & 1 & low & Fertilization \\
\hline 225 & Bodenbearbeitungsversuch am Galgenberg & Bingen-Büdesheim & 42 & 1 & very low & Tillage/Other \\
\hline \multicolumn{7}{|c|}{ Grassland LTFE } \\
\hline 10 & Stickstoffdüngung auf Grünland & Iden & 6 & 1 & & Fertilization \\
\hline 12 & Stickstoffdüngung auf Grünland & Hayn & 6 & 3 & & Fertilization \\
\hline 32 & Schachbrettversuch/Dauerdüngungsversuch auf Grünland & Daun & 7 & 4 & & Fertilization \\
\hline 46 & K-, P-, N-Steigerung zu Grünland & Freising & 14 & 4 & & Fertilization \\
\hline 95 & Grünlanddauerversuch (V102) & Paulinenaue & 28 & 1 & & Fertilization \\
\hline 118 & P-Düngungsversuch & St. Peter & 36 & 5 & & Fertilization \\
\hline 135 & Grünlandversuch Weiherwiese & Steinach & 31 & 3 & & Fertilization \\
\hline 141 & Kalk-Düngungsversuch & Rösrath & 36 & 4 & & Fertilization \\
\hline 163 & Grünlandversuch Veitshof & Veitshof & 43 & 3 & & Fertilization \\
\hline 164 & Statischer Dauerdüngungsversuch & Rotthalmünster & 38 & 3 & & Fertilization \\
\hline 168 & Phosphordüngung auf Grünland & Christgrün & 27 & 3 & & Fertilization \\
\hline 169 & Kaliumdüngung auf Grünland & Christgrün & 27 & 3 & & Fertilization \\
\hline 170 & Phosphordüngung auf Grünland & Forchheim & 27 & 4 & & Fertilization \\
\hline
\end{tabular}


Table A1. Continued.

\begin{tabular}{|c|c|c|c|c|c|c|}
\hline ID & LTFE name & Place of LTFE & $\begin{array}{r}\text { Address } \\
\text { (see below) }\end{array}$ & $\begin{array}{r}\text { CWBg } \\
\text { class }\end{array}$ & $\begin{array}{l}\text { MSQR } \\
\text { class }\end{array}$ & $\begin{array}{l}\text { Thematic } \\
\text { classification }\end{array}$ \\
\hline 171 & Kaliumdüngung auf Grünland & Forchheim & 27 & 4 & & Fertilization \\
\hline 172 & Phosphordüngung auf Grünland & Hayn & 6 & 3 & & Fertilization \\
\hline 173 & Kaliumdüngung auf Grünland & Hayn & 6 & 3 & & Fertilization \\
\hline 174 & Phosphordüngung auf Grünland & Iden & 6 & 1 & & Fertilization \\
\hline 175 & Kaliumdüngung auf Grünland & Iden & 6 & 1 & & Fertilization \\
\hline 176 & Phosphordüngung auf Grünland & Oberweißbach & 44 & 5 & & Fertilization \\
\hline 177 & Kaliumdüngung auf Grünland & Oberweißbach & 44 & 5 & & Fertilization \\
\hline 178 & Überprüfung der Kalkempfehlung für Grünland & Christgrün & 27 & 3 & & Fertilization \\
\hline 179 & Umweltbewusste Grünlandbewirtschaftung & Christgrün & 27 & 3 & & Fertilization/Other \\
\hline 180 & Grunddüngung im Grünland & Christgrün & 27 & 3 & & Fertilization \\
\hline 181 & Phosphordüngung auf Grünland & Heßberg & 44 & 3 & & Fertilization \\
\hline 182 & Kaliumdüngung auf Grünland & Heßberg & 44 & 3 & & Fertilization \\
\hline 183 & Phosphordüngung auf Grünland & Paulinenaue & 21 & 1 & & Fertilization \\
\hline 184 & Kaliumdüngung auf Grünland & Paulinenaue & 21 & 1 & & Fertilization \\
\hline 185 & Phosphordüngung auf Grünland & Wechmar & 44 & 2 & & Fertilization \\
\hline 186 & Kaliumdüngung auf Grünland & Wechmar & 44 & 2 & & Fertilization \\
\hline 187 & Niederblockland & Bremen & 45 & 2 & & Fertilization \\
\hline 188 & Kalkbedarf der Hochmoorkulturen & Bremen & 45 & 3 & & Fertilization \\
\hline 189 & Königsmoor/Nordheide & Bremen & 45 & 3 & & Fertilization \\
\hline 198 & Versuch 250 (Nährstoffmangelversuch) & Ihinger Hof & 46 & 4 & & Fertilization \\
\hline 199 & Versuch 251 (Wechseldüngungsversuch) & Ihinger Hof & 46 & 4 & & Fertilization \\
\hline
\end{tabular}

Institution addresses:

1 Landwirtschaftskammer Rheinland-Pfalz, Referat 21 Pflanzenbau, Burgenlandstr. 7, 55543 Bad Kreuznach

2 Helmholtz-Zentrum für Umweltforschung, Versuchsstation Bad Lauchstädt, Hallesche Straße 44, 06246 Bad Lauchstädt

3 Thüringer Landesamt für Landwirtschaft und Ländlichen Raum, Postfach 100 262, 07702 Jena

4 Humboldt-Universität zu Berlin, Lehr- und Forschungsstation, Bereich Pflanzenbauwissenschaften, Albrecht-Thaer-Weg 5, 14195 Berlin

5 Hochschule Anhalt, Fachbereich Landwirtschaft, Strenzfelder Allee 28, 06406 Bernburg

6 Landesanstalt für Landwirtschaft und Gartenbau, Strenzfelder Allee 22, 06406 Bernburg

7 Universität Bonn, Institut für Nutzpflanzenwissenschaften und Ressourcenschutz, Karlrobert-Kreiten-Str. 13, 53115 Bonn

8 Julius Kühn-Institut, Bundesforschungsinstitut für Kulturpflanzen, Messeweg 11/12, 38104 Braunschweig

9 Stabsstelle Boden des Thünen-Instituts, Bundesallee 50, 38116 Braunschweig

10 Julius Kühn-Institut, Bundesforschungsinstitut für Kulturpflanzen, Stahnsdorfer Damm 81, 14532 Kleinmachnow

11 Forschungsring e.V., Brandschneise 5, 64295 Darmstadt

2 YARA GmbH \& Co. KG, Hanninghof 35, 48249 Dülmen

13 Martin-Luther-Universität Halle-Wittenberg, Allgemeiner Pflanzenbau / Ökologischer Landbau, Betty-Heimann-Str. 5, 06120 Halle

14 Technische Universität München, Lehrstuhl für Pflanzenernährung, Emil-Ramann-Straße 2, 85354 Freising

5 Institut für Zuckerrübenforschung an der Georg-August-Universität Göttingen, Holtenser Landstr. 77, 37079 Göttingen

16 Justus-Liebig-Universität Gießen, Institut für Pflanzenbau und Pflanzenzüchtung I, Biomedizinisches Forschungszentrum Seltersberg, Schubertstraße 81, 35392 Gießen

17 Justus-Liebig-Universität Gießen, Lehr- und Versuchsbetrieb für ökologischen Landbau, 65606 Villm

18 Georg-August-Universität Göttingen, Abteilung Pflanzenbau, Von-Siebold-Str. 8, 37075 Göttingen

9 Georg-August-Universität Göttingen, Fakultät für Agrarwissenschaften, Carl-Sprengel-Weg 1, 37075 Göttingen

20 Leibniz-Institut für Gemüse- und Zierpflanzenbau, Theodor-Echtermeyer-Weg 1, 14979 Großbeeren

1 Landesamt für Verbraucherschutz, Landwirtschaft und Furneuordnung, Referat Ackerbau und Grünland, Berliner Straße, 14532 Stahnsdorf, OT Güterfelde

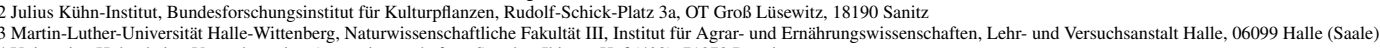

4 Universitat Hohenheim, Versuchsstation Agrarwissenschaten, Standort Minger Hof (403), 71272 Renningen

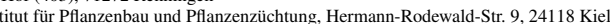

26 Agrarzentrum Limburgerhof, Speyerer Str. 2, 67117 Limburgerhof

27 Sächsisches Staatsministerium für Energie, Klimaschutz, Umwelt und Landwirtschaft, Abteilung 7, Referat 72, Wilhelm-Buck-Straße 2, 01097 Dresden

28 Leibniz-Zentrum für Agrarlandschaftsforschung, Eberswalder Str. 84, 15374 Müncheberg

29 Landwirtschaftskammer Niedersachsen, Bezirksstelle Hannover, Wunstorfer Landstr. 11, 30453 Hannover

30 unknown

31 Landesanstalt für Landwirtschaft, Institut für Ökologischen Landbau, Bodenkultur und Ressourcenschutz, Lange Point 6, 85351 Freising

32 Versuchsstation Klostergut Scheyern, 85298 Scheyern

33 Landwirtschaftliche Untersuchungs- und Forschungsanstalt Speyer, Obere Langgasse 40, 67346 Speyer

34 Humboldt-Universität zu Berlin, Lehr- und Forschungsstation Pflanzenbauwissenschaften, Thyrower Dorfstraße 9, 14959 Trebbin, OT Thyrow

35 Universität Hohenheim, Kleinhohenheim 1, 70599 Stuttgart-Schönberg

36 FEhS-Institut für Baustoff-Forschung e.V. (Forschungsgemeinschaft Eisenhüttenschlacken), Bliersheimer Straße 62, 47229 Duisburg

37 Universität Rostock, Agrar- und Umweltwissenschaftliche Fakultät, Justus-von-Liebig-Weg 6, 18059 Rostock

38 Staatliche Höhere Landbauschule Rotthalmünster, Franz-Gerauer-Straße 22-24, 94094 Rotthalmünster

39 SKW Stickstoffwerke Piesteritz GmbH, Möllensdorfer Straße 13, 06886 Lutherstadt Wittenberg

40 Landesamt für Ländliche Entwicklung, Landwirtschaft und Flurneuordnung, Neue Chaussee 3A, 14550 Groß Kreutz (Havel)

41 Landesforschungsanstalt für Landwirtschaft und Fischerei Mecklenburg-Vorpommern, Dorfplatz 1 / OT Gülzow, 18276 Gülzow-Prüzen

42 Technische Hochschule Bingen, Team Landwirtschaft und Umwelt, Berlinstraße 109, 55411 Bingen am Rhein

43 Technische Universität München, Lehrstuhl für Grünlandlehre, Alte Akademie 12, 85354 Freising

44 Thüringer Landesamt für Landwirtschaft und Ländlichen Raum, Naumburger

46 Universität Hohenheim, Fachgebiet Nachwachsende Rohstoffe in der Bioökonomie (340b), Fruwirthstraße 23, 70599 Stuttgart 
Data availability. The LTFE metadata are available in the BonaRes Repository: https://doi.org/10.20387/BonaRes-3tr6-mg8r (Grosse and Hierold, 2019).

Author contributions. The conceptualization was done by MG, $\mathrm{KH}$ and WH. The formal analysis was done by MG, MCA and HPP. $\mathrm{KH}$ supervised the study. The visualization was done by MG and MCA. MG prepared the article with contributions from all authors.

Competing interests. The authors declare that they have no conflict of interest.

Acknowledgements. Many thanks to Biljana Savic and Kevin Urbasch for help with GIS-analyses. Many thanks to three anonymous referees for most valuable and in-depths comments.

Financial support. This research has been supported by the German Federal Ministry of Education and Research (BMBF) in the framework of the funding measure "Soil as a Sustainable Resource for the Bioeconomy - BonaRes (Module B): BonaRes Centre for Soil Research, subproject B" (grant nos. 031A608B and 031B0511B).

The publication of this article was funded by the Open Access Fund of the Leibniz Association.

Review statement. This paper was edited by Peter Fiener and reviewed by three anonymous referees.

\section{References}

Ad-hoc-AG Boden: Manual of soil mapping, 5th Edn. (KA5), edited by: Eckelmann, W., Sponagel, H., Grottenthaler, W., Hartmann, K.-J., Hartwich, R., Janetzko, P., Joisten, H., Kühn, D., Sabel, K.-J., Traidl, R., Schweizerbart'sche Verlagsbuchhandlung, Hannover, 2005.

Ad-hoc-AG Boden: Methodendokumentation Bodenkunde. Auswertungsmethoden zur Beurteilung der Empfindlichkeit und Belastbarkeit von Böden. Auszug: Kapitel 6.3 Ackerbauliches Ertragspotential eines Standorts, 2010.

Amberger, A. and Gutser, R.: Effect of long-term potassium fertilization on crops and potassium dynamics of a brown earth (Weihenstephan), Ann. Agron., 27, 643-657, 1976.

Askari, M. S., Cui, J., and Holden, N. M.: The visual evaluation of soil structure under arable management, Soil Till. Res., 134, 1-10, https://doi.org/10.1016/j.still.2013.06.004, 2013.

Bai, Z. C., T., Ruiperez Gonzalez, M., Batjes, N. H., Mäder, P., Bünemann, E. K., de Goede, R., Brussaard, L., Xu, M., Ferreira, C. S. S., Reintam, E., Fan, H., Mihelič, R., Glavan, M., and Tóth, Z.: Effects of agricultural management practices on soil quality: A review of long-term experiments for Europe and China, Agr. Ecosyst. Environ., 265, 1-7, https://doi.org/10.1016/j.agee.2018.05.028, 2018.
Berti, A., Marta, A. D., Mazzoncini, M., and Tei, F.: An overview on long-term agro-ecosystem experiments: Present situation and future potential, Eur. J. Agron., 77, 236-241, https://doi.org/10.1016/j.eja.2016.01.004, 2016.

BGR (Bundesanstalt für Geowissenschaften und Rohstoffe): Nutzungsdifferenzierte Bodenübersichtskarte von Deutschland 1:1.000.000 - Auszug Ackerboden, available at: https://www.bgr.bund.de/DE/Themen/Boden/Produkte/Karten/ Downloads/BUEK1000N_Acker.pdf (last access: 20 November 2020), 2007.

BGR (Bundesanstalt für Geowissenschaften und Rohstoffe): Ackerbauliches Ertragspotential der Böden in Deutschland. Bewertet nach dem Müncheberger Soil Quality Rating - Final Rating $(1: 1.000 .000)$ auf Basis der BÜK1000N, available at: https://www.bgr.bund.de/DE/Themen/Boden/Bilder/Bod_ SoilQualityRating1000_g.html (last access: 23 November 2020), 2014.

BonaRes: Soil as a Sustainable Resource for the Bioeconomy BonaRes, available at: https://www.bonares.de/, last access: 10 September 2020.

Ciaccia, C., Ceccarelli, D., Antichi, D., and Canali, S.: Long-term experiments on agroecology and organic farming: the Italian long-term experiment network, in: Long-Term Farming Systems Research. Ensuring Food Security in Changing Scenarios, edited by: Bullar, G. and Riar, A., Academic Press, London, 183-196, 2020.

CLC (Corine Land Cover): Version 20, available at: https: //land.copernicus.eu/pan-european/corine-land-cover/clc2018/ (last access: 24 September 2020), 2018.

Crimmins, S. M., Dobrowski, S. Z., Greenberg, J. A., Abatzoglou, J. T., and Mynsberge, A. R.: Changes in climatic water balance drive downhill shifts in plant species' optimum elevations, Science, 331, 324-327, https://doi.org/10.1126/science.1199040, 2011.

Daedlow, K., Lemke, N., and Helming, K.: Arable Land Tenancy and Soil Quality in Germany: Contesting Theory with Empirics, Sustainability-Basel, 10, 2880, https://doi.org/10.3390/su10082880, 2018.

Debreczeni, K. and Körschens, M.: Long-term field experiments of the world, Arch. Acker Pfl. Boden, 49, 465-483, https://doi.org/10.1080/03650340310001594754, 2003.

DWD (Deutscher Wetterdienst): Index of climate environment CDC grids Germany multi annual water balance, available at: https://opendata.dwd.de/climate_environment/CDC/grids_ germany/multi_annual/water_balance/, last access: 10 September 2020 .

Ellerbrock, R. H. and Gerke, H. H.: Analyzing ManagementInduced Dynamics of Soluble Organic Matter Composition in Soils from Long-Term Field Experiments, Vadose Zone J., 15, 1-10, https://doi.org/10.2136/vzj2015.05.0074, 2016.

Ellerbrock, R. H., Kersebaum, K. C., and Kaiser, M.: Isolation and characterization of soil organic matter fractions different in solubility as a possibility to evaluate and to improve C-pools in C-turnover models, Arch. Acker Pfl. Boden, 51, 209-219, https://doi.org/10.1080/03650340400026644, 2005.

ESDAC (European Soil Data Centre): European Commission, Joint Research Centre: https://esdac.jrc.ec.europa.eu, last access: 29 July 2020. 
ESRI: ArcMap 10.6.1, available at: https://desktop.arcgis.com/de/ arcmap (last access 20 November 2020), 2018.

Franko, U., Kolbe, H., Thiel, E., and Liess, E.: Multi-site validation of a soil organic matter model for arable fields based on generally available input data, Geoderma, 166, 119-134, https://doi.org/10.1016/j.geoderma.2011.07.019, 2011.

GLTEN: Global Long-Term Agricultural Experiment Network, available at: https://www.glten.org/experiments, last access: 9 September 2020.

Grosse, M. and Hierold, W.: Long-term Field Experiments in Germany [Data set], BonaRes, https://doi.org/10.20387/BonaRes3tr6-mg8r, 2019.

Grosse, M., Heinrich, U., and Hierold, W.: Fact Sheet for the Description of Long-Term Field Experiments/Steckbrief zur Beschreibung von Dauerfeldversuchen, https://doi.org/10.20387/BonaRes-R56G-FGRW, 2019.

Hamidov, A., Helming, K., Bellocchi, G., Bojar, W., Dalgaard, T., Ghaley, B. B., Hoffmann, C., Holman, I., Holzkämper, A., and Krzeminska, D.: Impacts of climate change adaptation options on soil functions: A review of European case-studies, Land Degrad. Dev., 29, 2378-2389, https://doi.org/10.1002/ldr.3006, 2018.

Hanauer, T., Pohlenz, C., Kalandadze, B., Urushadze, T., and Felix-Henningsen, P.: Soil distribution and soil properties in the subalpine region of Kazbegi; Greater Caucasus; Georgia: Soil quality rating of agricultural soils, Ann. Agric. Sci., 15, 1-10, https://doi.org/10.1016/j.aasci.2016.12.001, 2017.

Kaiser, M., Piegholdt, C., Andruschkewitsch, R., Linsler, D., Koch, H. J., and Ludwig, B.: Impact of tillage intensity on carbon and nitrogen pools in surface and sub-surface soils of three long-term field experiments, Eur. J. Soil Sci., 65, 499-509, https://doi.org/10.1111/ejss.12146, 2014.

Körschens, M.: Dauerfeldversuche: Übersicht, Entwicklung und Ergebnisse von Feldversuchen mit mehr als 20 Jahren Versuchsdauer, Akademie der Landwirtschaftswissenschaften, Berlin, 1990.

Körschens, M.: Der Statische Düngungsversuch Bad Lauchstädt nach 90 Jahren: Einfluss der Düngung auf Boden, Pflanze und Umwelt: mit einem Verzeichnis von 240 Dauerfeldversuchen der Welt, B.G. Teubner Verlagsgesellschaft, Leipzig, 1994.

Körschens, M.: Die wichtigsten Dauerfeldversuche der Welt Übersicht, Bedeutung, Ergebnisse, Arch. Acker Pfl. Boden, 42, 157-168, https://doi.org/10.1080/03650349709385724, 1997.

Körschens, M. (Ed.): IOSDV: Internationale organische Stickstoffdauerdüngungsversuche. Bericht der Internationalen Arbeitsgemeinschaft Bodenfruchtbarkeit in der Internationalen Bodenkundlichen Union (IUSS), UFZ-Bericht, 15/2000, Bad Lauchstädt, 2000.

Körschens, M.: The importance of long-term field experiments for soil science and environmental research - a review, Plant Soil Environ., 52, 1-8, 2006.

Körschens, M., Albert, E., Baumecker, M., Ellmer, F., Grunert, M., Hoffmann, S., Kismanyoky, T., Kubat, J., Kunzova, E., Marx, M., Rogasik, J., Rinklebe, J., Rühlmann, J., Schilli, C., Schröter, H., Schroetter, S., Schweizer, K., Toth, Z., Zimmer, J., and Zorn, W.: Humus und Klimaänderung - Ergebnisse aus 15 langjährigen Dauerfeldversuchen, Arch. Acker Pfl. Boden, 60, 1485-1517, https://doi.org/10.1080/03650340.2014.892204, 2014.

Macholdt, J., Piepho, H.-P., and Honermeier, B.: Mineral NPK and manure fertilisation affecting the yield stability of winter wheat:
Results from a long-term field experiment, Eur. J. Agron., 102, 14-22, https://doi.org/10.1016/j.eja.2018.10.007, 2019a.

Macholdt, J., Piepho, H.-P., and Honermeier, B.: Does fertilization impact production risk and yield stability across an entire crop rotation? Insights from a long-term experiment, Field Crops Res., 238, 82-92, https://doi.org/10.1016/j.fcr.2019.04.014, 2019b.

Merbach, W. and Deubel, A.: Long-term field experiments - museum relics or scientific challenge?, Plant Soil Environ., 54, 219226, https://doi.org/10.17221/395-PSE, 2008.

Mueller, L., Schindler, U., Mirschel, W., Graham Shepherd, T., Ball, B. C., Helming, K., Rogasik, J., Eulenstein, F., and Wiggering, H.: Assessing the productivity function of soils. A review, Agron. Sustain. Dev., 30, 601-614, https://doi.org/10.1051/agro/2009057, 2010.

Onofri, A., Seddaiu, G., and Piepho, H.-P.: Long-term experiments with cropping systems: case studies on data analysis, Eur. J. Agron., 77, 223-235, https://doi.org/10.1016/j.eja.2016.02.005, 2016.

Payne, R. W.: The design and analysis of long-term rotation experiments, Agron. J., 107, 772-785, 2015.

Pereira, L. S., Allen, R. G., Smith, M., and Raes, D.: Crop evapotranspiration estimation with FAO56: Past and future, Agr. Water Manage., 147, 4-20, https://doi.org/10.1016/j.agwat.2014.07.031, 2015.

Piepho, H.-P. and Vo-Thanh, N.: Die Gleitmethode nach Mitscherlich und was sie mit Geostatistik zu tun hat, J. Kulturpflanzen, 72, 527-540, https://doi.org/10.5073/JfK.2020.10-11.03, 2020.

Reckling, M., Döring, T. F., Bergkvist, G., Stoddard, F. L., Watson, C. A., Seddig, S., Chmielewski, F. M., and Bachinger, J.: Grain legume yields are as stable as other spring crops in long-term experiments across northern Europe, Agron. Sustain. Dev., 38, 63, https://doi.org/10.1007/s13593-018-0541-3, 2018.

Richter, C. and Kroschewski, B.: Analysis of a long-term experiment with repeated-measurement models, J. Agron. Crop. Sci., 192, 55-71, 2006.

Sandén, T., Spiegel, H., Stüger, H. P., Schlatter, N., Haslmayr, H. P., Zavattaro, L., Grignani, C., Bechini, L., D’Hose, T., Molendijk, L., Pecio, A., Jarosz, Z., Guzmán, G., Vanderlinden, K., Giráldez, J. V., Mallast, J., ten Berge, H., and Aitkenhead, M.: European long-term field experiments: knowledge gained about alternative management practices, Soil Use Manage., 34, 167-176, https://doi.org/10.1111/sum.12421, 2018.

Sattar, A., Khan, S. A., and Banerjee, S.: Climatic water balance for assessment of growing season in the eastern Indian state of Bihar, Mausam, 70, 569-580, 2019.

Singh, M. and Jones, M. J.: Modeling yield sustainability for different rotations inlong-term barley trials, J. Agric. Biol. Environ. Stat., 7, 525-535, 2002.

Smolentseva, E., Smolentsev, B., Pachkin, K., and Mueller, L.: Assessing the Soil Quality and Crop Yield Potentials of Some Soils of Eurasia, in: Novel Measurement and Assessment Tools for Monitoring and Management of Land and Water Resources in Agricultural Landscapes of Central Asia, edited by: Mueller, L., Saparov, A., Lischeid, G., Environmental Science and Engineering, Springer, Cham, 2014.

Techen, A.-K., Helming, K., Brüggemann, N., Veldkamp, E., Reinhold-Hurek, B., Lorenz, M., Bartke, S., Heinrich, U., Amelung, W., and Augustin, K.: Soil research challenges in response to emerging agricultural 
soil management practices, Adv. Agron., 161, 179-240, https://doi.org/10.1016/bs.agron.2020.01.002, 2020.

TERENO: Terrestrial Environmental Observatories, available at: https://www.tereno.net/joomla/index.php, last access: 9 September 2020 .

Umweltbundesamt: UBA Metadatenkatalog. CORINE Land Cover Deutschland [Data set], available at: https://gis.uba.de/catalog/ OpenSearch.do?type=/Query/OpenSearch.do\&search=CORINE (last access: 24 September 2020), 2019.
Vogel, H.-J., Eberhardt, E., Franko, U., Lang, B., Ließ, M., Weller, U., Wiesmeier, M., and Wollschläger, U.: Quantitative Evaluation of Soil Functions: Potential and State, Front. Environ. Sci., 7, 164, https://doi.org/10.3389/fenvs.2019.00164, 2019. 